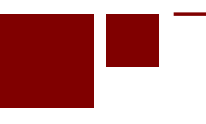

C E N T E R for RETIREMENT RES E A R C H at BOSTON COLLEGE

\title{
THE RELATIVE EFFECTS OF ECONOMIC AND NON-ECONOMIC FACTORS ON TAXPAYERS' PREFERENCES BETWEEN FRONT-LOADED AND BACK-LOADED RETIREMENT SAVINGS PLANS
}

\author{
Andrew D. Cuccia, Marcus M. Doxey, and Shane R. Stinson \\ CRR WP 2017-7 \\ July 2017
}

Center for Retirement Research at Boston College

Hovey House

140 Commonwealth Avenue

Chestnut Hill, MA 02467

Tel: 617-552-1762 Fax: 617-552-0191

http://crr.bc.edu

\begin{abstract}
Andrew D. Cuccia is an associate professor and a Grant Thornton faculty fellow at the University of Oklahoma. Marcus M. Doxey and Shane R. Stinson are assistant professors at the University of Alabama. The research reported herein was pursuant to a grant from the U.S. Social Security Administration (SSA) funded as part of the Retirement Research Consortium. The findings and conclusions expressed are solely those of the authors and do not represent the views of SSA, any agency of the federal government, the University of Oklahoma, the University of Alabama, or Boston College. The authors would like to gratefully acknowledge Diana Falsetta, Mary Hamman, Daniela Hochfellner, Anne Magro, Michael Roberts, Tim Rupert, Donna Bobek Schmitt, and workshop participants at the 2015 and 2017 Behavioral Tax Symposia, the 2017 Annual Conference of the Western Economic Association International, the University of Alabama, and the University of South Carolina for their thoughtful comments and suggestions.
\end{abstract}

(C) 2017, Andrew D. Cuccia, Marcus M. Doxey, and Shane R. Stinson. All rights reserved. Short sections of text, not to exceed two paragraphs, may be quoted without explicit permission provided that full credit, including (C) notice, is given to the source. 


\section{About the Steven H. Sandell Grant Program}

This paper received funding from the Steven H. Sandell Grant Program for Junior Scholars in Retirement Research. Established in 1999, the Sandell program's purpose is to promote research on retirement issues by scholars in a wide variety of disciplines, including actuarial science, demography, economics, finance, gerontology, political science, psychology, public administration, public policy, sociology, social work, and statistics. The program is funded through a grant from the Social Security Administration (SSA). For more information on the Sandell program, please visit our website at: http://crr.bc.edu/?p=9570, send e-mail to crr@bc.edu, or call (617) 552-1762.

\section{About the Center for Retirement Research}

The Center for Retirement Research at Boston College, part of a consortium that includes parallel centers at the University of Michigan and the National Bureau of Economic Research, was established in 1998 through a grant from the Social Security Administration. The Center's mission is to produce first-class research and forge a strong link between the academic community and decision-makers in the public and private sectors around an issue of critical importance to the nation's future. To achieve this mission, the Center sponsors a wide variety of research projects, transmits new findings to a broad audience, trains new scholars, and broadens access to valuable data sources.

Center for Retirement Research at Boston College

Hovey House

140 Commonwealth Ave

Chestnut Hill, MA 02467

Tel: 617-552-1762 Fax: 617-552-0191

http://crr.bc.edu

Affiliated Institutions:

The Brookings Institution

Syracuse University

Urban Institute 


\begin{abstract}
To understand the potential impact of tax incentives on individual retirement saving, we must understand how individuals make decisions about saving. We examine individual taxpayers’ choices between front-loaded (e.g., traditional) and back-loaded (e.g., Roth) defined contribution retirement savings plans, as well as their saving levels and investment style choices within a plan. To do so, we conduct a series of experiments that allow us to consider individualspecific expectations regarding the economic factors that normatively drive retirement saving decisions, as well as non-economic attitudes and preferences that may also impact these decisions. Overall, we find that participants generally prefer back-loaded retirement plans to front-loaded plans. We find mixed evidence regarding whether individuals appropriately weight expected tax rate changes in their plan choices, despite the fact that these tax rate changes are the primary factor driving the relative after-tax returns of front- and back-loaded plans. Conversely, we find evidence that plan attributes related to individuals’ non-economic attitudes and preferences consistently influence plan choice. Saving levels, while idiosyncratic and difficult to predict, are negatively associated with preference for back-loaded plans and may be influenced by tax-related contextual variables as well. Investment risk is also negatively associated with preferences for back-loaded plans.
\end{abstract}

The paper found that:

- Taxpayers prefer back-loaded plans over front-loaded plans.

- Individuals may not systematically rely on their beliefs regarding their relative tax rates when making plan choices. At least part of that failure is due to a lack of awareness and/or understanding.

- Individual saving levels and investment selections, while largely idiosyncratic and difficult to predict, are negatively associated with a preference for back-loaded plans and may be influenced by tax-related contextual variables as well.

The policy implications of the findings are:

- The fact that features of the tax law provide non-economic (dis)utility beyond their impact on expected returns (1) suggests that neither the potential effectiveness of alternative savings incentives nor taxpayers’ investment choices should be evaluated 
purely based on their financial efficacy; and (2) provides evidence of a systematic preference for a particular savings incentive not discernible from analytical or archival analysis.

- Our results suggest that individuals, on average, do not respond "rationally" to the relative economic incentives associated with alternatively structured plans. Further, although errors can be reduced with tax-related guidance, our evidence illustrates that individuals systematically incorporate non-economic factors into their retirement plan choices, often leading to a preference for back-loaded plans even when such a choice is economically adverse.

- While archival data show that retirement savers utilize front-loaded plans to a much greater extent than back-loaded Roth plans (70.6 percent vs. 23.1 percent of defined contribution retirement accounts) (Copeland 2015), the fact that we find a strong preference for back-loaded plans across several experiments and conditions suggests that the greater use of front-loaded plans is an artifact of artificial barriers to participation in back-loaded plans (e.g., income limitations, employer plan offerings, etc.). 


\section{Introduction}

With the decline of defined benefit retirement plans (Anderson 2013), the importance of personal retirement savings is growing. Further, while Congress provides several types of savings incentives through the tax law, many studies show that people are not accumulating enough money for retirement due to a combination of insufficient savings and suboptimal investment decisions (e.g., Banks et al. 1998; Benartzi and Thaler 1999, 2001, 2007). The current study examines how individuals initially choose between tax-favored plans with various structures.

Tax-favored retirement savings vehicles generally take one of two forms. In "frontloaded” plans, contributions are immediately deductible or excludable, and earnings accrue taxfree. However, all withdrawals of contributions and earnings are taxed as ordinary income. Examples of front-loaded plans include traditional individual retirement accounts (IRAs) and 401(k)s. In contrast, "back-loaded” plans provide no deduction or exclusion for contributions, but all qualified withdrawals of contributions and earnings are tax-free. Examples include Roth IRAs and 401(k)s. In some cases, taxpayers can choose between front- and back-loaded plans. In other cases, that choice may be limited, either by statutory participation restrictions or by benefit providers who provide only one plan type. This complexity and disparity in circumstances surrounding retirement planning has prompted some legislators to propose consolidating all tax-favored savings vehicles into one with no choice as to its form. ${ }^{1}$

Whether taxpayers benefit from a choice between forms of savings vehicles and, absent a choice, which form can be expected to lead to greater overall savings, are open questions. Although front-and back-loaded plans can produce economically equivalent returns and incentives under a reasonable set of assumptions, in reality they often have very different effects on after-tax returns. The differences are due primarily to the relation between a taxpayer's current tax rate and the rate they will face in retirement. This relation is itself a result of numerous environmental and taxpayer-specific factors, many of which are unknown to the taxpayer when making savings decisions. This makes ex-ante economic analysis a daunting task for most taxpayers. Further, differently structured plans may differentially impact an individual's non-economic utility. Some plan features may be directly related to factors that

\footnotetext{
${ }^{1}$ For example, the President's Advisory Panel on Tax Reform (2005) recommended the adoption of a single retirement savings account with increased limits on annual contributions, income ceilings lifted, and a single type of tax incentive, either front- or back-loaded.
} 
provide non-economic (dis)utility (e.g., dread, uncertainty aversion, general preferences to prepay for or debt-finance consumption). Other plan features may interact with the decision environment (e.g., the time between when the savings decision is made and when its consequences are experienced) to impact an individual's non-economic utility.

To determine how tax law can best encourage retirement savings requires an understanding of how saving decisions are made. Specifically, we are interested in the following issues: (1) do people understand and respond to the economic factors that impact the relative after-tax returns of front- and back-loaded plans; (2) do non-economic factors moderate the impact of these economic factors; (3) do non-economic factors create a systematic preference for front- or back-loaded plans; and (4) might that preference differ across the contexts in which individuals make savings decisions? However, addressing these issues by examining the outcomes of those decisions available in archival data is problematic. As discussed above, both plan types are not available to all taxpayers. Even if both plan types were available to all taxpayers, evaluating judgments and preferences based on objective, publicly observed information can be misleading if those judgments are driven by unobservable contextual factors or subjective beliefs and attitudes.

Because archival data provide limited insight into the beliefs and attitudes investors use to make savings decisions, we examine our questions using a series of experiments. In each, we present participants with the choice of tax-favored retirement plans that are identical in all respects except the timing of the tax benefits. We also vary the timing of the savings decision relative to the actual contribution and its related tax consequences. These contexts simulate conditions in which the retirement planning decision is temporally removed from the contribution and its consequences (as when planning year-ahead 401(k) contributions) and those in which the decision produces an immediate contribution and related tax consequences (as when taxpayers make retroactive contributions to an IRA). The experiments differ primarily in the way in which tax rate changes are captured, either by explicitly manipulating them, holding them constant, or eliciting participants’ expectations ex post.

Overall, as expected, we consistently find that taxpayers prefer back-loaded plans over front-loaded plans. However, the evidence regarding the impact of tax rates on plan choice is mixed. Tax rate changes significantly impacted plan choice when participants received a tutorial regarding their economic effects, and when participants were not educated but were 
experimentally and randomly assigned to tax rate change conditions (necessarily prompting their potential significance to the decision but not the nature of that significance) and paid based on the economic outcomes of their decisions. However, tax rate changes had no impact on plan choices when participants were neither explicitly educated on the economic impact of tax rate changes in advance nor explicitly prompted regarding the change they will face in tax rates over time. The results of these experiments suggest that individuals may not systematically rely on their beliefs regarding their relative tax rates when making plan choices. Further, although at least part of that failure is due to a lack of understanding, taxpayer preferences appear to be driven at least as much by non-economic factors that are systematically related to plan features and the decision context as they are by the economic effects caused by changing tax rates. Finally, our analyses suggest that individual savings levels and investment selections, while largely idiosyncratic and difficult to predict, are negatively associated with preference for backloaded plans, and may be influenced by tax-related contextual variables as well.

This study increases our understanding of how economic and non-economic factors interact to impact taxpayers' relative preferences for tax-favored retirement plans. Policymakers can use this information when weighing how to effectively encourage retirement savings and educate taxpayers about savings incentives. More specifically, the fact that features of the tax law provide non-economic (dis)utility beyond their impact on expected returns (1) suggests that neither the potential effectiveness of alternative savings incentives nor taxpayers' investment choices should be evaluated purely based on their financial efficacy; and (2) provides evidence of a systematic preference for a particular savings incentive not discernible from analytical or archival analysis.

\section{Background and Hypotheses Development}

\section{Economic Factors and Retirement Plan Choice}

It can be shown that the after-tax return available from front-loaded plans is equivalent to the after-tax return available from back-loaded plans as long as (1) the taxpayer can reinvest the initial tax savings generated by the front-loaded plan at the same rate of return in the same or a similar tax-deferred investment and (2) the tax rate applicable to current deductions is equal to that on eventual withdrawals (see Appendix for analysis). ${ }^{2}$ Assuming that a taxpayer can

\footnotetext{
${ }^{2}$ As currently structured, penalties on early withdrawals can also differentially impact the return across front- and
} 
reinvest the current tax savings from a front-loaded plan in the same or a similar tax-favored account, ${ }^{3}$ the primary economic factor impacting plan choice is the direction of any expected tax rate changes, which depends on the taxpayer's earnings pattern as well as temporal changes in the statutory tax rate. ${ }^{4,5,6}$ Clearly, the taxpayer knows neither with certainty when considering retirement savings. However, his or her strategy should be to accelerate (defer) taxes on retirement funds with a back-loaded (front-loaded) plan when he or she expects tax rates during retirement to be greater (lower) than they are when contributions are made.

The above discussion leads to the following hypothesis:

H1: Taxpayers expecting their tax rate in retirement to be higher (lower) than their current rate are more likely to prefer a back-loaded (front-loaded) retirement plan.

Several factors could cause individuals to seemingly fail to properly incorporate expected tax rate changes into their plan choices. One is that individuals may be unaware of the relevance and nature of the economic impact of expected tax rate changes on relative after-tax returns available from the plans, with their failure to incorporate this factor into their choice representing a judgment error. Alternatively, their choice may also incorporate non-economic factors unrelated to financial returns. As we do not expect taxpayers to have universal understanding of the economic relation between tax rate changes and relative plan performance, we hypothesize the following:

H2: Educating taxpayers regarding the impact of tax rate changes on the relative returns

2 ...back-loaded plans. However, there is no reason that penalties cannot be structured to be neutral across forms. Therefore, this study does not address the impact of differential penalty structures across incentive forms.

${ }^{3}$ The ability to reinvest immediate tax savings into the tax-favored plan is a reasonable assumption based on prior research suggesting that taxpayers contribute significantly less to such plans than they are statutorily allowed (Clements 2006; Bryant and Sailer 2006; Copeland 2007, 2015). However, any restriction on the ability to reinvest the tax savings from a front-loaded plan in a tax-deferred vehicle increases the relative return of a back-loaded plan. ${ }^{4}$ In fact, a significant increase in tax rates can reduce the return of a front-loaded plan below that of a taxable account. Conversely, Burman, Gale and Weiner (2001) document significant negative effective tax rates for amounts invested in front-loaded accounts around the 1986 tax rate reductions.

${ }^{5}$ Burman et al. (2001) provide a more detailed analysis of the choice between front- and back-loaded plans, including the effect of interest rates and investment horizons when contribution limits are constrained to be equal across plans.

${ }^{6}$ Hewitt Associates (2006), examining choices between front- and back-loaded 401(k)s, reports greater participation in Roth $401(\mathrm{k}) \mathrm{s}$ by those in their twenties, and presumably facing a lower tax rate, than by those in their fifties. Similarly, they report higher participation by non-highly compensated employees in Roth plans than in traditional ones. Copeland (2014) similarly reports that participants in Roth plans are younger, on average, than those in frontloaded plans. While these results are consistent with taxpayers expecting their tax rates to be higher in retirement preferring back-loaded plans, it is unclear whether the relations are due to tax rate expectations or other factors that may be confounded with age and/or current tax rates (e.g., the stickiness of prior decisions, willingness to adopt a new innovation). 
of back- and front-loaded retirement plans will increase the impact of expected tax rate changes on plan choice.

\section{Non-economic Factors and Retirement Plan Choice}

As suggested above, taxpayers' preferences for front- or back-loaded plans may be impacted by a number of non-economic factors. Below, we describe several such factors that may be directly related to features of the plans themselves or which may be related to the interaction of the plan features with the context in which the choice is made.

\section{Psychological Factors Directly Related to Plan Features}

Prospective Mental Accounting. The traditional discounted utility model suggests that people will evaluate purchase decisions by comparing the discounted present value of the utility stream flowing from a purchase against the discounted present value of the payments required. Therefore, the model suggests that people will choose to pay for consumption so as to minimize the net present value of the related costs. Prelec and Loewenstein (1998) propose an alternative, descriptive "double-entry" mental accounting model in which experienced utility is evaluated by two sets of mental accounting entries: one which records the discounted "net" utility derived from consumption and the other that records the discounted "net" disutility resulting from the related payment. However, the net experienced utility of consumption includes a reduction for the related salient costs, and the net experienced disutility of a payment includes a reduction for the related consumption so that all benefits (costs) are considered twice, once directly when consumed (paid) and once when they buffer the experienced effect of the payment (benefit). Simply put, merely thinking about the cost of a purchase can undermine the pleasure derived from it while thinking about the pleasure of consumption can blunt the pain of paying for it.

The model is guided by several mental accounting assumptions, including prospective mental accounting. Prospective mental accounting suggests that future events are weighted heavily in the evaluation of net utility and/or disutility while prior events are heavily discounted or ignored. This increases the overall utility of prepaid items since the net utility from the later consumption is little reduced by the prior payment, while the net disutility from the earlier payment is reduced relatively more by the pending consumption. Conversely, it reduces the 
overall utility of debt financing/deferred payments since the net utility from earlier consumption is reduced by the looming payment but the net disutility from the later payment is not buffered by the prior consumption. This leads to a general preference for prepaying for consumption over debt financing, especially for consumption items with little or no future utility flows to buffer the later payments. ${ }^{7}$

Prelec and Loewenstein (1998) support their predictions in a series of surveys. For example, they find that their typical respondent preferred paying for a beach vacation either in a year prior to, or concurrent with, actually taking the vacation, and disliked the idea of paying a year after taking it. This particular result also supports the idea that people can anticipate the reduction in future pleasure resulting from unpaid costs. If taxes are perceived as the cost of retirement income/consumption, taxpayers may anticipate greater overall net utility from the income if the related tax is paid prior to its receipt as in a back-loaded plan. At withdrawal, the previously paid taxes are relatively unlikely to detract from the utility of the income.

Conversely, with a front-loaded plan, taxpayers may consider the tax cost of the savings twice; once indirectly at the time of contribution when the savings are set aside and again upon receipt when the taxes are actually paid.

FRAMING AND INTERTEMPORAL REFERENCE POINTS. Research suggests that an individual's choice between current and future consumption will depend on how that choice is framed (Loewenstein 1988; Loewenstein and Prelec 1992). Intertemporal options can be viewed as choices to expedite or delay consumption relative to an adopted temporal referent point, producing offsetting gains and losses. For example, a person expecting to receive $\$ 100$ today may have the opportunity to delay the receipt, trading an immediate loss (i.e., the forfeiture of an immediate \$100) for a future gain (i.e., the $\$ 100$ received in the future). Similarly, a person expecting to receive $\$ 100$ in the future may have the opportunity to expedite the receipt to today, trading an immediate gain (i.e., the current \$100) for a future loss (i.e., the forfeiture of \$100 in the future). Since losses generally loom larger than gains (Kahneman and Tversky 1979; Tversky and Kahneman 1991), any choice framed as an intertemporal change regarding the

\footnotetext{
${ }^{7}$ Of course, the potential effects of prospective mental accounting are independent of any direct discounting of delayed receipts and payments and any benefit of prepayment may be insufficient to overcome the discounting of a delayed benefit.
} 
timing of positive outcomes will result in a net reduction in utility. Shelley (1993) expanded Loewenstein's model to include intertemporal choices between negative outcomes like cash payments. Similar to positive outcomes, a choice to defer (expedite) a negative outcome results in the trade-off of an immediate gain (loss) in exchange for a future loss (gain).

In addition to potential framing effects resulting from changes in the timing of realized outcomes, the outcome itself will be psychologically discounted if deferred. However, it has been suggested that positive outcomes face larger discount rates than do negative outcomes (Thaler 1981; Benzion, Rapoport, and Yagil 1989; Loewenstein 1988; Shelley 1993), meaning that expediting positive outcomes is more valuable than is deferring negative outcomes.

If taxpayers adapt to paying taxes currently on income, investment in a front-loaded savings vehicle might be framed as a deferral of that tax, or the trade of an immediate gain for a future loss. Such framing and related loss aversion would result in the pending loss overshadowing the corresponding gain. Further, the relatively light discounting of the future loss provides little compensation for the deferral. Together, this suggests that a front-loaded plan might provide taxpayers less overall utility than that derived from the tax savings alone. Conversely, taxpayers may be less likely to frame participation and non-participation in a backloaded plan as competing temporal prospects. When considering a back-loaded plan, income is taxed currently regardless of participation. With no offsetting gains/losses, no negative intertemporal framing effects should be expected. Therefore, for a taxpayer considering investing in a tax-favored savings plan, a front-loaded plan will compare less favorably with the status quo than will a back-loaded plan. ${ }^{8}$

DREAD. Research suggests that there is disutility in the "dread" associated with anticipating future aversive events and utility in the anticipation of future pleasant events (Loewenstein 1987; Hardman 2009). Under some circumstances savoring (dread) can lead to a preference to delay (accelerate) desirable (undesirable) outcomes inconsistent with traditional economic models of discounted utility. The conditions under which such negative discounting might be expected include those in which the impact of the outcome is fleeting and/or can be vividly imagined (e.g., Loewenstein 1987).

\footnotetext{
${ }^{8}$ Though front-loaded plans may serve as referents for back-loaded plans, this is less likely given a taxpayer making a choice whether to save or not (versus a choice of changing from a front-loaded to a back-loaded plan).
} 
Research also suggests that U.S. taxpayers have largely negative views about tax-related issues (Hardisty et al. 2010) and find the federal income tax filing and payment process to be aversive and administratively complex (Moon 2009). Taxpayers seem to view the payment/savings of tax as a relatively vivid event with the payment of taxes often prompting visceral reactions. The duration of the consequences, however, is usually relatively short. In most cases, the tax paid, or immediately saved, on a single retirement plan contribution has little long-term impact on a particular taxpayer. If taxpayers focus on the benefits of tax-favored savings (i.e., the tax savings), the opportunity to savor the delayed benefits of a back-loaded plan may make those benefits more attractive than the economically equivalent benefits available from a front-loaded plan. Similarly, if taxpayers focus on the taxes actually paid, they may prefer to "get it over with" and pay those taxes now, as required of a back-loaded plan, avoiding the dread associated with the looming payment required by a front-loaded plan. In general, we expect a pattern of taxation in which aversive events (paying taxes on current income) precede pleasant events (tax-free investment earnings and qualified withdrawals) to be preferable to a pattern of taxation in which pleasant events (tax exclusions and/or deductions) precede aversive events (paying taxes on retirement distributions).

UNCERTAINTY. Finally, people generally dislike uncertainty (Allais 1953; Einhorn and Hogarth 1985; Kahneman and Tversky 1979). With respect to retirement plan preferences, we posit that a back-loaded plan may be seen as a relatively more "certain” prospect because the taxpayer knows both the tax rate on current contributions and, therefore, the amount of taxes being paid, as well as the tax (none) that will be due on subsequent earnings and qualifying withdrawals. Neither future tax rate changes nor the taxpayer's economic status will impact the amount of taxes paid and saved. On the other hand, although a taxpayer knows how much tax they may save currently with contributions to a front-loaded plan, they cannot know the amount of taxes that may be due on withdrawals nor, therefore, the benefits derived from participation.

The above factors (while a non-exhaustive list) all point in the same direction; all else equal, back-loaded plans will provide taxpayers greater non-economic utility than do front-loaded plans, increasing taxpayers' preferences for back-loaded plans. Thus, we posit the following:

H3: Holding economic factors constant, taxpayers have a preference for back-loaded plans over front-loaded plans. 


\section{Psychological Factors Related to the Interaction of Plan Features and Context}

The impact of some psychological factors may depend of the interaction of plan features with the decision context. For example, a taxpayer's preference for a front- or back-loaded plan is likely affected by the tax payment/refund currently due (i.e., their tax settlement position) and the temporal distance between the savings decision and its consequences. For instance, research consistently suggests that taxpayers who owe additional taxes at the time of filing frame the payment as a loss (White et al. 1993; Jackson and Hatfield 2005; Brink and Lee 2015). Loss aversion suggests that taxpayers will be highly motivated to reduce that loss. One way to do so is by making tax-deferred contributions to a front-loaded retirement plan. However, when the consequences of a contribution decision are temporally removed from the decision, the ability of any tax savings resulting from the contribution to cushion the loss are reduced. Therefore, we expect the effect of a taxpayer's settlement position will be greater when making a retrospective contribution decision than when making a temporally distant prospective contribution decision.

H4: The impact of settlement position on plan choice will be moderated by the temporal distance between the contribution decision and the consequences of the decision.

\section{Method and Results}

As discussed above, archival data confound choices between front-loaded and backloaded plans with real-world barriers to participation, both observable (e.g., income limitations) and unobservable (e.g., the menu of plans offered by each employer). Further, taxpayers' reasons for selecting from available front- or back-loaded plans are also unobservable in archival data (i.e., we cannot determine their understanding of the economic incentives, their expectations regarding tax rate changes, nor the effect of psychological factors on their choices). Thus, to examine our research questions, we conduct a series of online experiments with participants recruited through Amazon's Mechanical Turk (MTurk). The experiments differ primarily in the way in which beliefs regarding tax rate changes are captured, either by explicitly manipulating them, holding them constant, or eliciting participants' expectations ex post. For each experiment, we screened participants to include U.S. citizens between the ages of 19 and 59 (i.e., adults under the standard minimum age to take qualifying retirement distributions) who are currently employed or self-employed, participate in their household's financial decisions, and have previously filed an income tax return.

We recruited participants for all experiments through MTurk for two primary reasons. 
First, because taxpayers who are eligible to contribute to tax-preferred retirement accounts constitute a broad cross-section of society, we did not want to limit our sample to university students (a largely homogenous population with respect to age and education) or to a single employer (a homogenous population with respect to access to employer-sponsored retirement plans). Prior studies note that the population of MTurk workers is more heterogeneous and more representative of the U.S. population as a whole than the population of university students, specifically with respect to age, education, and income (Paolacci et al. 2010; Farrell, Grenier, and Leiby2017). Farrell et al. (2017) also demonstrate that MTurk workers are just as honest and hardworking as university students (or more so) with respect to their participation in online studies, and Buchheit et al. (2017) demonstrate that MTurk workers are, on average, as intelligent as university students. Although MTurk workers are generally younger and more educated than the general population of the U.S. (e.g., Hitlin 2016), they are more diverse than are other internet-based samples and provide data that meet the standards associated with published social science research (Buhrmester, Kwang and Gosling 2011).

\section{Experiment 1}

Experiment 1 is designed to examine participants’ sensitivity to economic factors underlying the choice of retirement plans as well as the impact of several non-economic factors.

\section{Decision Task}

After agreeing to participate in the study, participants first provided their annual income, how often they were paid from their primary occupation, the amount of payment owed or refund due on their last tax return, and estimates of their current marginal tax rate. ${ }^{9}$ We used this information to construct participant-specific decision tasks, described below, that participants would find both relatable and credible, thereby enhancing construct and external validity. Each participant then read about two tax-favored plans, one whose tax benefits were back-loaded and the other front-loaded. The plans were similar in all respects other than the timing of tax

\footnotetext{
${ }^{9}$ Specifically, we asked participants to estimate their current marginal tax rate by estimating the amount of additional taxes they would have paid on their most recent tax return had they earned an additional \$100 of taxable income. We then showed each participant how this estimate translates to a marginal tax rate (i.e., the extra estimated tax divided by \$100) and asked them to confirm or revise their estimate before moving on with the experiment.
} 
benefits. ${ }^{10}$ Though we explained the workings of each plan on the same screen of our instrument, we randomized the order in which each was presented and explained.

Next, we asked participants whether or not they would like to participate in either one of the available plans, the total amount they would like to contribute, how they would like to allocate their contribution between the plans, and which of the two plans they would choose if they could only contribute to one. Participants responded to the last question on a scale of 1 (definitely the back-loaded plan) to 6 (definitely the front-loaded plan). For analysis purposes, all responses were reduced by 3.5 so that a positive (negative) value represents a preference for a front-(back-)loaded plan. ${ }^{11}$

\section{Independent Variables}

To examine $\mathrm{H} 1$ regarding the impact of expected tax rate changes on plan choice, we elicited participants' expectations of whether their tax rate in retirement would be higher or lower than their current rate (-3 [3] = expect rates in retirement to be much lower [higher]). We also asked participants how confident they were of that opinion $(0=$ no confidence at all; $100=$ absolutely certain). To avoid demand effects, tax rate expectations were always elicited after the dependent variable.

To examine $\mathrm{H} 2$ regarding whether a lack of reliance on tax rates was an error due to a lack of understanding and/or to the reliance on other factors that might impact plan preferences, we used a method similar to that used by Loewenstein and Sicherman (1991) (see also Slovic and Tversky 1974 and MacCrimmon 1968) to examine whether individuals’ violations of economic axioms were due to decision making errors or to informed choices that incorporate non-economic factors. We provided half of the participants an explanation of the impact of tax rate increases and decreases on the relative after-tax returns across the plans. To ensure our “educated” participants understood this relation, a comprehension check required them to

\footnotetext{
${ }^{10}$ Current front-loaded and back-loaded plans differ on several dimensions unrelated to their tax treatment (e.g., participation restrictions, the timing of required distributions, etc.). As we are interested only in the inherent taxrelated differences in such accounts, we explicitly described the plans as being similar to each other on all dimensions other than those described (e.g., they had similar rules covering withdrawals, including early withdrawals, investment options, etc.). Further, to reduce the chances of participants incorporating any information they might have brought with them to the study regarding existing plans, we explicitly told them that the plans differed from currently available plans in that neither had any limits on participation, contributions, or the timing of withdrawals. The plan descriptions are included in Exhibit 1.

${ }^{11}$ Participants indicating they would not contribute to either plan were asked to assume that they were required to contribute a minimum amount (e.g., three percent of their wages) to a plan.
} 
identify the plan that would produce the highest accumulated retirement savings in three different scenarios, one each in which a taxpayer expects their tax rates to increase, remain the same, and decrease. ${ }^{12}$ Exhibit 1 includes illustrations of this manipulation. Participants could not continue until they identified the plan that provided the highest retirement savings in each scenario. To minimize the possibility of demand effects, and to give participants "permission" to make a choice consistent with any non-economic preferences, the instructions on the education screen ended with the following statement: "Of course, predicting future tax rates may be difficult, and other factors might make one plan more personally appealing than the other regardless of the potential economic impact of tax rate changes. Therefore, there is no 'right' plan choice in any situation.”

We hypothesize in $\mathrm{H} 3$ that several psychological factors will create a general preference among taxpayers for back-loaded plans. Although we expect these psychological factors to affect individual plan preferences in the same direction, the extent to which they describe individual attitudes and/or preferences will vary across individuals. That variance, along with the ability to solicit the individual attitudes of study participants, allows us to examine the potential impact of each of those non-economic factors. Following our retirement savings task and manipulation checks, we asked participants a series of questions to identify their psychological attitudes and preferences believed to impact their plan choice.

To capture general preferences for prepaying for consumption, as might result from employing prospective mental accounting, we asked participants whether they would prefer to finance living expenses during a month of unemployment by saving money monthly prior to unemployment or to pay the same amount monthly after resuming work (assuming no interest would be incurred) (adapted from Prelic and Loewenstein 1998). Reponses ranged from 1 (strongly prefer after resuming work) to 7 (strongly prefer saving prior to unemployment). ${ }^{13}$

To capture the extent that participants framed each plan as a temporal trade-off of tax

\footnotetext{
12 To control for our participants' pre-experimental financial sophistication, which might weaken our education manipulation, we factor analyzed their self-reported household income, total formal education, the number of business (i.e., finance, accounting, economics and tax) courses they had taken, and a self-assessment of their relative knowledge of personal finance and investing ( $-3=$ far below the average person; $3=$ far above the average person). These factors have been used previously to measure individual financial sophistication (e.g., Calvert, Campbell and Sodini 2009; Muller and Weber 2010; Smith, Finke and Huston 2011). All measures loaded on a single factor explaining 43 percent of the variance in the responses. All variables had factor loadings of at least 0.44 with the exception of household income, which had a loading of 0.28 .

${ }^{13}$ Respondents were asked a similar question regarding payment for a vacation. Responses were significantly correlated $(r=.54 ; p<0.001)$.
} 
costs and savings, we asked participants which of the following statements best described their view of a back- (front-) loaded plan: “A: The potential tax savings on my contributions (withdrawals) directly increased the taxes I would otherwise have to pay in retirement (currently)." and "B: The potential tax savings on my contribution (withdrawals) had no direct impact on the taxes I would otherwise have to pay in retirement (currently).” Response scales were anchored at 1 (entirely A; directly related) and 7 (entirely B; not related). The extent to which participants linked the tax savings and costs of a back-loaded plan more than they did a front-loaded plan was measured by taking the difference between a participants' response to each question.

To capture participants’ level of dread regarding a looming financial liability, we asked participants the most they would pay currently to avoid having to pay $\$ 5,000$ at three points in the future: one year, ten years, and twenty years (adapted from Loewenstein 1987). We constructed two measures of dread for each participant by subtracting the amount they would pay to avoid the payment if due in 10 and 20 years from what they would pay to avoid it if due in one year and dividing the difference by the one year amount. ${ }^{14}$ The two measures were highly correlated $(\mathrm{r}=0.876 ; \mathrm{p}<0.0001)$. We then factor analyzed the responses to create a single variable intended to measure a participant's dread of future payments.

To identify the relative uncertainty participants associated with different plans, we asked which plan, back-loaded or front-loaded, they felt was “riskier” (back-loaded, front-loaded, or neither). We further asked them about their level of agreement ( $1=$ strongly disagree to $7=$ strongly agree) with a series of statements describing the following as "unpredictable” for each plan: the total taxes they would pay, the amount of taxes they save, and the total funds available upon retirement. We compared responses across plan types and factor analyzed the difference scores to produce a measure of relative uncertainty perceptions across plans. A factor analysis confirmed that all difference scores loaded on a single factor that explained 59 percent of the total variance in responses.

We hypothesize in $\mathrm{H} 4$ that a taxpayer's payment/refund position at filing will impact plan choice, but that the impact will be moderated by the temporal proximity of the taxpayer's potential plan contribution/tax savings to their contribution decision. As described above, we

\footnotetext{
${ }^{14}$ Note that our measure for participants who positively discounted the future payments falls between 0 and 1 . Conversely, the measure has no lower limit for those who may have negatively discounted the future payments. For these participants, the lower limit of the measure was set at -1 .
} 
elicited participants' payment/refund status on their most recent return, as well as the amount due to/owed by them, in the initial information-gathering stage of the experiment. During the decision phase of the task, we incorporated this information into each participant's personalized decision scenario. By including participants’ own payment/refund condition in the decision context rather than manipulating the variable and randomly assigning participants to a payment/refund condition, participants should better internalize and relate to the decision task, thereby enhancing both construct and external validity (Copeland and Cuccia 2002).

To capture the temporal distance between (1) the savings decision and (2) the contribution and its tax consequences, we asked each participant to make contribution decisions in two randomly ordered contexts. ${ }^{15}$ One was in the context of choosing whether to make a retroactive contribution while filing a tax return with tax due or a refund approximately equal to their most recent return (i.e., an IRA-type context). ${ }^{16}$ In this context, a contribution to a frontloaded plan immediately reduces a pending loss when the participant owes taxes. In the other decision context, participants chose how much, if any, of the next year's paychecks they would like to save in a retirement account, similar to an annual 401(k) election. ${ }^{17}$ Therefore, the consequences of the contribution decision were relatively removed from the decision itself.

\section{Experiment 1 Participants}

Two hundred and eighty-three participants completed Experiment 1. Participants received a fixed fee of $\$ 2.25$ and took an average of 27.05 minutes to complete the instrument, yielding an average hourly wage of $\$ 4.99 .^{18,19}$ Our participants are similar to those recruited in

\footnotetext{
${ }^{15}$ In addition to randomizing the order of our decision sets, we informed participants before making either set of decisions that the two contexts are independent, inherently different, and should be considered separately from one another. This is reiterated after the first set of decisions when participants are explicitly told that, given that the situations differ, their second set of decisions may or may not be similar to their first.

${ }^{16}$ To make sure participants understand the consequences of their participation and allocation decisions, the impact of their decisions on their return settlement amount (based on an estimate of their current marginal tax rate elicited prior to the decision tasks) is provided to them after making their decision. They are then given the opportunity to modify their decisions (similar to prompts included in popular tax preparation software). Their final decisions are used as the dependent variables.

${ }^{17}$ In the introduction to the experiment, participants report their annual income and how often they are paid. The contribution decision is then framed relative to their regular paycheck (e.g., "How much of a monthly pre-tax income of \$X would you contribute to the available plans?”

${ }^{18}$ This amount is above the average effective wage reported in a number of prior studies using MTurk subjects (e.g. Paolacci et al. 2012; Rennekamp 2012; Brandon et al. 2014; Brasel et al. 2016) and is reasonable for MTurk subjects (Farrell et al. 2017).

${ }^{19}$ This approach is also consistent with Bonner et al. (2000), who suggest that relatively complex tasks featuring judgment and choice are less likely to benefit from performance incentives than simpler tasks.
} 
prior studies using MTurk (e.g., Buchheit et al. 2017; Stinson et al. 2017). As shown in Table 1, their mean age is 36 years. Forty-three (57) percent are female (male). They have a mean family income of approximately $\$ 67,000$ and are reasonably well-educated with 57 percent completing a bachelor's degree or higher. More germane to our study, 69 percent of participants report personally saving for retirement and 78 percent live in a household in which someone saves for retirement. Participants believed they faced an average marginal tax rate of 20 percent. Fortysix (34) percent believed their tax rate in retirement would be higher (lower), reporting an average expected rate of 23 percent. Participants were moderately confident when predicting their tax rates in retirement, reporting an average confidence level of 52 percent ( $0=$ no confidence at all; 100 = absolutely certain).

\section{Experiment 1 Results}

\section{Preliminary Analyses}

Overall, 72 (54) percent of participants chose to contribute to a retirement plan in the 401(k)-type (IRA-type) context. Average voluntary contributions in the 401(k)-type (IRA-type) context was 4.8 (1.3) percent of household income. Thirty-six (37) percent of 401(k) (IRA) contributors chose to split their contributions between front- and back-loaded plans. Overall, 64 (65) percent of 401(k) (IRA) contributions were allocated to back-loaded plans. ${ }^{20}$

As described above, participants receiving the education manipulation were not allowed to continue with the study until they correctly identified the plan that would produce the greatest retirement savings given a taxpayer's expected tax rate changes. To further test the effectiveness of our manipulation and provide a basis of comparison to the uneducated participants, we provided all participants descriptions of front- and back-loaded plans post-experimentally and asked which would produce the greatest retirement savings under increasing, decreasing, or constant tax rates. Seventy-two (35) percent of the participants receiving (not receiving) education correctly answered all three post-experiment questions $\left(\chi^{2}=42.34 ; \mathrm{p}<0.001\right)$.

\section{Hypotheses Tests}

We report initial multivariate tests of H1-H3 in column 1 of Table $2 .{ }^{21}$ The expectation

\footnotetext{
${ }^{20}$ Those forced to make a contribution were more likely to allocate it across plan types, but the overall allocation across plan types remained fairly consistent when all respondents were considered.

${ }^{21}$ Preliminary analyses were conducted including as variables (1) the order in which back- and front-loaded plans
} 
of an increasing tax rate is positively associated with choosing a back-loaded plan $(\mathrm{p}=0.005)$. However, the significant interaction of rate change expectation with the education manipulation $(p=0.020)$ suggests that the impact of expected rate changes differs across the education manipulation. Follow-up tests, reported in columns 2 and 3 of Table 2, show that expected tax rate changes had no impact on plan type choices absent education ( $\mathrm{p}=0.710 \mathrm{vs.}<0.001)$. Results did not differ across the two decision contexts. ${ }^{22}$

The above results suggest that, contrary to H1, participants do not incorporate expected tax rate changes into their plan choice without an explicit explanation of the impact tax rate changes have on relative after-tax returns. Further, consistent with H2, this failure is related, at least in part, to participants’ naiveté. However, evidence also suggests that decisions do reflect a general preference for back-loaded plans, as predicted in H3. Even when participants were educated about the rate change-return relation, 49 percent who reported that they expected their tax rates to be lower in retirement nonetheless elected to make their contributions to a backloaded plan. Conversely, only 18 (20) percent of those who reported that they expected their tax rates to be higher in retirement nonetheless selected to make their immediate (future) contributions to a front-loaded plan.

We next consider the impact of specific psychological factors on participants’ plan choices. The means and correlations of the continuously-measured non-economic factors are presented in Table 3. As illustrated, participants, on average, prefer to prepay for consumption $(\mathrm{p}<0.001)$ and positively discount future payments $(\mathrm{p}<0.001)$. As expected, they link the tax costs and savings of a front-loaded plan more than they do a back-loaded plan $(\mathrm{p}<0.001)$ and see the tax costs and savings of a front-loaded plan as more uncertain than those of a back-loaded plan $(\mathrm{p}<0.001)$. None of the psychological variables differ across the education manipulation at traditional levels, nor does financial sophistication. As illustrated in Panel B, temporal framing is positively correlated with the preference for prepayment $(\mathrm{p}=0.04)$ and negatively correlated with relative perceptions of uncertainty $(\mathrm{p}=0.003)$. However, a factor analysis with a varimax rotation finds that none of the variables load highly on the same factor (i.e., no factor has more

were presented to participants, (2) the order in which IRA- and 401(k)-type plans were presented to participants, (3) participants' financial sophistication, and (4) participant liquidity as well as the interactions of each with the variables of interest. As neither order variable nor liquidity were found to have a main effect, nor significantly moderate any variables of interest, we present results excluding these variables.

${ }^{22}$ Though the tax rate change by decision context interaction was significant when no education was provided, simple effects tests indicate that expected tax rate changes impacted plan choices in neither the immediate $(\mathrm{p}=0.352)$ nor delayed $(\mathrm{p}=0.840)$ contexts (results not tabulated). 
than one variable with a factor loading greater than 0.23 ).

To examine the effects of each of these non-economic factors on plan choice, we add them (except temporal framing), and their interactions with the economic variables of interest, to the model. ${ }^{23}$ The expanded model, presented in Panel A of Table 4, shows that several noneconomic factors impact plan choice. Uncertainty has a significant $(\mathrm{p}<0.001)$ main effect on plan choice. Although neither prepayment preferences nor dread have a significant main effect on plan choice, they both significantly moderate the rate change expectation by education interaction $(\mathrm{p}<0.001$ and $\mathrm{p}=0.070$, respectively). Follow-up tests, reported in columns B and C of Panel A of Table 4, show that the rate change expectation by education interaction reported above is stronger for the nearly 73 percent of participants who have a general preference for prepaying for consumption ( $<<0.001$ vs 0.027 ). The rate change by education interaction was marginally significant $(\mathrm{p}=0.093)$ for the 63 participants demonstrating negative discounting of future losses but were not significant at all for those demonstrating positive discounting ( $\mathrm{p}=0.524)$ (results not tabulated).

In addition, the model presented in Panel A of Table 4 shows that tax return settlement position has a significant main effect $(\mathrm{p}=0.048)$ on plan choice. However, its effect is not moderated by the temporal distance between the reporting decision and the realization of the contribution's tax consequences ( $\mathrm{p}=0.812$; not tabulated), providing limited support for H4. Further, settlement position does not moderate the impact of tax rate expectations nor is it involved in any higher-order interaction involving rate expectations. Finally, to accompany our model in Panel A of Table 4, we present means in Panels B through E that highlight particular cells of interest.

\section{Participant Savings Levels}

In addition to testing our hypotheses on initial selections between front- and back-loaded retirement savings plans in Experiment 1, we assess individual savings levels (i.e., contributions relative to available income) within chosen plans. We find in a series of untabulated analyses that participants contributed significantly more in the temporally distant condition resembling

\footnotetext{
${ }^{23}$ Analyses regressing the main effects of tax rate changes, education, financial sophistication and each of the economic factors on each plan choice separately find no independent variable with a variance inflation factor greater than 2, suggesting that the correlations noted above had no impact on our reported results. However, an analysis including temporal framing rather than uncertainty finds that temporal framing significantly $(\mathrm{p}=0.052)$ impacted plan choice.
} 
prospective 401(k) elections than the temporally proximate condition resembling retroactive IRA elections (7.76 percent of income compared to 2.05 percent; repeated measures ANOVA $\mathrm{F}=72.757, \mathrm{p}<0.001$; Paired T-test $\left.\mathrm{t}_{282}=8.530, \mathrm{p}<0.001\right)$. This trend was unaffected by participants’ preferences for back-loaded vs. front-loaded retirement plans (all p-values 0.67 and above).

Regressing contribution rates in the IRA-type condition on a number of variables including refund position, expected tax rate change, and education using bootstrapped coefficients produced only one significant coefficient at the $\mathrm{p}=0.05$ level. Not surprisingly, participants who reported a sense of urgency with respect to retirement savings contribute more on average $(\mathrm{p}=0.035)$. However, owing tax is marginally, positively associated with IRA-type contribution rates ( $\mathrm{p}_{\text {two-tailed }}=0.078$ ). The education manipulation is marginally, negatively associated with IRA-type contribution rates ( $\mathrm{p}_{\text {two-tailed }}=0.086$ ).

Regressing 401(k)-type contribution rates using the same model produces two significant and two marginally significant coefficients. Participants who have experience contributing to a tax preferred retirement account contributed more $(\mathrm{p}=0.035)$, while a factor score measuring participants' predilection for procrastination and abdication of responsibility tended to save less $(\mathrm{p}=0.007)$. As with the IRA-type contributions, 401(k)-type contribution rates are marginally, positively associated with owing tax in the most recent year $(\mathrm{p}=0.101)$. Concerns about insufficient liquidity are also negatively associated with 401(k)-type contribution rates ( $\mathrm{p}=0.054$ ). Overall, savings levels appear to be largely idiosyncratic decisions as the adjusted $\mathrm{R}^{2}$ is just 0.087 for the IRA-type regression model and 0.086 for the 401(k)-type model.

\section{Experiment 2}

Experiment 2 focuses directly on whether and how non-economic factors influence plan choice (i.e., H3 and H4). We do this by setting both current and retirement tax rates equal to the participant's estimate of their current tax rate, thus eliminating any economic differences between the plans. As it was important that all participants understood the economic equivalence, all received the education treatment described above for Experiment 1. All other aspects of Experiment 2 are identical to Experiment 1.

\section{Experiment 2 Participants}

Two hundred and ninety-three participants completed Experiment 2 (see Table 1). 
Seventy-three percent currently participate in a tax-preferred plan. They took an average of 27 minutes to complete the instrument yielding an average hourly wage of approximately $\$ 5$. Preliminary Analyses

Overall, 72 (52) percent of all participants in Experiment 2 chose to make future (immediate) contributions to a plan. Average voluntary future (immediate) contributions were 5.3 (1.7) percent of household income. Forty-two (41) percent of future (immediate) contributors chose to split their contributions between front- and back-loaded plans. Overall, 65 (60) percent of future (immediate) contributions were allocated to back-loaded plans. ${ }^{24}$

The means and correlations of the continuously-measured non-economic factors are presented in Table 5. As in Experiment 1, participants perceive front-loaded plans as more uncertain ( $<<0.001$ ), prefer to prepay for consumption ( $<<0.001)$, and link the tax costs and savings of a front-loaded plan more than they do a back-loaded plan $(\mathrm{p}<0.001)$. Unlike Experiment 1, temporal framing is correlated with neither dread $(\mathrm{p}=0.452)$, nor the preference for prepayment ( $\mathrm{p}=0.748)$, nor perceptions of uncertainty $(\mathrm{p}=0.972)$. However, uncertainty perceptions are significantly correlated with prepayment preferences $(\mathrm{p}=0.036)$ and financial sophistication ( $\mathrm{p}=0.013$ ). A factor analysis with a varimax rotation finds that uncertainty perceptions and prepayment preference load on the same factor with factor loadings of 0.40 and 0.33, respectively. No other variables load highly on the same factor (i.e., no factor has more than one variable with a factor loading greater than 0.20 ).

\section{Hypotheses Tests}

We regressed the non-economic factors examined above on participants' plan choices to further investigate their relation. Results are reported in Table 6. Consistent with the findings in Experiment 1, we find that financial sophistication and uncertainty perceptions significantly impact plan choice. Less financial sophistication $(\mathrm{p}=0.020)$ and a perception that back-loaded plans are more uncertain $(\mathrm{p}<0.001)$ reduce the attractiveness of a back-loaded plan. We further find that, when the impacts of financial factors are controlled, a preference for back-loaded plans is associated with a general preference for prepaying for consumption $(\mathrm{p}=0.074)$. Those who

\footnotetext{
${ }^{24}$ When also considering those who were required to make a contribution, the average contribution was reduced, as would be expected. However, rather than making a haphazard choice, those forced to make a contribution were more likely to allocate it across plan types. Further, the allocation across plan types remained fairly consistent when all respondents were considered.
} 
judged the tax costs and savings of a front-loaded plan as relatively more related to each other also tend to prefer back-loaded plans $(\mathrm{p}=0.001)$. However, although dread moderated the rate change by education interaction in Experiment 1, it had no main effect on plan choice in Experiment 2 ( $\mathrm{p}=0.454)$. Consistent with $\mathrm{H} 4$, the impact of participants' settlement position on plan choice differs across temporal conditions $(\mathrm{p}=0.041)$. As expected, settlement position has no impact on plan choice when the consequences of the choice are temporally removed from the choice $(\mathrm{p}=0.388$ ) but does impact choice when the consequences are temporally close $(\mathrm{p}=0.016)$ (results not tabulated).

\section{Participant Savings Levels}

As in Experiment 1, we also examine individual savings levels in Experiment 2. Our participants again contributed significantly more in the temporally distant 401(k)-type condition compared to the temporally proximate IRA-type condition (10.38 percent vs. 3.07 percent of income; repeated measures ANOVA $\mathrm{F}=62.089$, $\mathrm{p}<0.001$; paired-t-test $\mathrm{t}_{292}=7.880, \mathrm{p}<0.001$ ). Preference for back-loaded vs. front-loaded plans also had no effect on savings rates for Experiment 2 regardless of temporal distance (all p-values 0.441 or above).

Regressing IRA-type contribution rates on a number of variables including refund position and expected tax rate change using bootstrapped coefficients produced only one significant coefficient at the $\mathrm{p}=0.05$ level. In this instance, the number of dependents is positively associated with IRA-type contributions $(\mathrm{p}=0.020)$. A sense of urgency related to retirement planning is marginally, positively associated with IRA-type contributions ( $\mathrm{p}=0.069)$.

Regressing 401(k)-type contribution rates using the same model produces two significant coefficients and one marginally significant coefficient. Once again, a sense of urgency for retirement savings is positively associated with contribution rates $(\mathrm{p}=0.038)$ while a factor measuring participants' concern with their tax position (tax due/refund) is negatively associated with contributions $(\mathrm{p}=0.003)$. Self-reported confusion with taxes in general is marginally, positively associated with 401( $\mathrm{k}$ )-type contributions ( $\mathrm{p}=0.099)$. As noted in Experiment 1 , explaining the variation in contribution rates is a difficult task. For Experiment 2, the adjusted $\mathrm{R}^{2}$ statistics for the IRA-type and 401(k)-type contribution rate models are 0.018 and 0.070 , respectively. 


\section{Experiment 3}

Experiments 1 and 2 used information gathered directly from participants to create personalized retirement savings scenarios to maximize the external validity and realism of our task. However, because we elicited important factors such as withholding position, current and expected tax rates, and income from our participants, participants were not randomly assigned to manipulated variables (with the exception of education). As a result, the possibility remains that unmeasured variables correlated with the elicited variables could be driving our results. To address this concern, we designed Experiment 3 to maximize internal validity by controlling the decision context and randomly assigning participants to different levels of the decision-relevant factors of interest.

\section{Decision Task}

In Experiment 3, participants were endowed with a fixed amount of earned income. As in Experiments 1 and 2, participants decided whether or not they would like to participate in either of two available plans, the total amount they would like to contribute, and how they would like to allocate their contribution between the plans. At the end of the experiment, participants were compensated based on the amount of total current and lifetime consumption generated by their experimental earnings.

Participants began Experiment 3 by reading standard IRB disclosures and information regarding payment for their participation and answering comprehension checks related to these items. $^{25}$ Next, participants read a scenario in which they had earned an annual income of $\$ 50,000$ and faced a current average tax rate of 15 percent, resulting in a potential tax liability of $\$ 7,500$. They were further instructed that $\$ 40,000$ of their income was required to pay tax withholding and essential living expenses over the course of the year, leaving $\$ 10,000$ available to save. We next explained to participants that their task was to determine the amount of their available cash balance that they wished to "spend" on current consumption and the amount that they wished to "save" for retirement. Spending resulted in immediate utility, operationalized as

\footnotetext{
${ }^{25}$ We required all participants to correctly answer comprehension checks in several places before they could proceed to our retirement decision scenarios and receive payment for completing the study. If a participant incorrectly answered a comprehension check, he or she was expelled from the survey, but could start over from the beginning (facing a new randomly assigned condition) if desired. Thus, all participants who took part in and received payment for the main experimental task had already demonstrated their understanding of the key components of the decision context. As detailed later, this design choice produced a high passage rate for post-task manipulation checks, and we made very few eliminations from our sample of complete and paid responses.
} 
an immediate payment equal to $\$ 0.03$ for every $\$ 1,000$ spent. The amount saved could be invested in one of two “mutual funds," generating an additional payment of \$0.03 for every $\$ 1,000$ of principal savings and accumulated investment earnings, after taxes. The funds varied in risk and loss potential, but both had overall positive expected returns compared to the zero expected return (and zero possible loss) from spending. ${ }^{26}$ Finally, we informed participants that any taxes due or tax refund at the end of the exercise would be deducted from or added to their cash balance after their savings decision.

After correctly answering a number of comprehension checks related to the decision scenario and compensation scheme, participants viewed the back- and front-loaded plan descriptions (identical to those used in Experiments 1 and 2) and were reminded that both retirement plans offer the same "mutual fund” investment options. After answering additional comprehension checks over the new information, participants again saw the retirement plan descriptions and chose whether and how much to "spend," "save” in the front-loaded plan, and "save” in the back-loaded plan.

The instrument concluded with a post-experimental questionnaire including manipulation checks and a summary of the participant's investment results and compensation.

\section{Independent Variables}

As described above, we manipulated three variables in Experiment 3, producing a fully crossed 2 (tax rate change) $\times 2$ (decision timing) $\times 2$ (withholding position) between-subjects design. We manipulate tax rate changes by telling participants that their tax rate in retirement will either be higher (TAXES UP_-increasing from 15 to 20 percent in retirement) or lower (TAXES DowN-decreasing from 15 to 10 percent in retirement) than their current tax rate.

We manipulate decision timing by placing participants in a scenario where they are asked either to plan their retirement savings behavior for the upcoming year (DISTANT) or to make the savings decision while completing the tax return for the year in question (IMMEDIATE). ${ }^{27}$

\footnotetext{
${ }^{26}$ Consistent with Stinson et al. (2017), each participant was given a distribution of possible annual returns for two hypothetical mutual funds. Mutual Fund A offered relatively conservative investment strategy featuring low upside and downsize potential, producing an expected annual return of approximately 8\%. On the other hand, Mutual Fund $\mathrm{B}$ was a relatively aggressive investment, featuring greater upside and downside potential that produced an expected annual return of approximately $13 \%$.

27 The IMMEDIATE condition is made possible by the fact that the tax code currently allows taxpayers to make IRA savings contributions for the preceding year through April $15^{\text {th }}$. The DISTANT condition is more akin to the annual elections process for an employer-sponsored (e.g., 401(k)) account, which often occurs several months prior to the
} 
Although the information provided to all participants was sufficient to calculate their expected tax liability $(\$ 7,500)$ and tax due or refund $(\$ 500)$ in all conditions, the expected tax due or refund amount was made explicit in the IMMEDIATE condition.

Finally, we manipulate settlement position at two levels by adjusting participants' assigned tax withholding levels in the scenario. ${ }^{28}$ Participants in the REFUND (TAX DUE) condition were told that they had already paid $\$ 8,000(\$ 7,000)$ of their tax liability through withholding. ${ }^{29}$

\section{Experiment 3 Participants}

We received 328 complete responses for Experiment 3 (see Table 1). Participants are demographically similar to those in Experiments 1 and 2. Participants report a mean current tax rate of approximately 19 percent, similar to the 20 percent mean tax rates reported in Experiments 1 and 2. Participants earned an average of $\$ 2.13$ (comprised of a $\$ 1.55$ fixed showup fee plus the bonus for every $\$ 1,000$ in a participant’s ending balance) and took a mean of 29.83 minutes to complete the instrument, yielding an average hourly wage of $\$ 4.28$, also similar to Experiments 1 and 2.

With respect to real-life tax positions and experience, our sample appears to match our experimental parameters quite well, indicating that we achieved a reasonable level of realism in the quantitative aspects of the experiment. Mean (median) income is $\$ 50,497(\$ 46,500)$, which matches well with the $\$ 50,000$ taxable income parameter in the experiment. Participants’ median marginal tax rate is 15 percent, which matches the current tax rate parameter of the

\footnotetext{
filing of an income tax return.

${ }^{28}$ The manipulation of prepayment position remedies the unbalanced distribution of prepayment position observed in experiment one and two where the distribution was approximately 80 percent refunds. One reason that the interaction of timing and prepayment position was not significant in experiment one may be the small number of participants who experience a tax due position.

${ }^{29}$ The $\$ 40,000 / \$ 10,000$ allocation of taxable income was displayed to all participants in the REFUND condition and did not include the tax refund itself, which participants were not allowed to "save" in a retirement plan (i.e., tax refunds only resulted in more "spending" money at the end of the exercise). However, since we required any additional taxes owed at the end of the study to be paid from a participant's available cash balance before calculating his or her final balance and bonus payments, part of a participant's disposable income in the TAX DUE condition was already "spoken for." Thus, in order to provide participants in both prepayment conditions with the same amount of unallocated investment capital (i.e., funds unencumbered by taxes), we changed the dedicated and available cash balances to $\$ 39,500$ and $\$ 10,500$, respectively, for TAX DUE participants. In other words, TAX DUE participants were shown a $\$ 10,500$ available cash balance and were immediately given enough information to determine that only $\$ 10,000$ was not already "spoken for" in the form of taxes at the onset of the retirement decision.
} 
experiment. ${ }^{30}$ The majority of our participants also have experience saving for retirement; 82 percent of participants' households currently save for retirement with a mean (median) savings rate of 12.34 (10.00) percent of annual income.

\section{Experiment 3 Results}

The primary dependent variable we use to test our hypotheses is the ratio of back-loaded savings to total savings, RотнRATIO. To test our hypotheses, we conducted an ANOVA on ROTHRATIO with tax rate changes (TAXES UP vs. TAXES DOWN), decision timing (DISTANT vs. IMMEDIATE), and withholding position (TAX DUE vs. REFUND) as factors. Table 7 displays the ANOVA results. Consistent with H1, we find a main effect of tax rate changes on ROTHRATIO with TAXES UP resulting in a significantly higher ROTHRATIO than TAXES DOWN. ${ }^{31}$

Consistent with H3, Table 8, Panel A shows that participants preferred the back-loaded retirement plan to the front-loaded plan across all cells at a rate of 60.9 percent to 39.1 percent, significantly different from a 50/50 split $\left(\mathrm{t}_{254}=5.193\right.$, $\left.\mathrm{p}_{\text {(one-tailed) }}<0.001\right)$. When we examine the contribution rates by individual cell, the pattern holds. The back-loaded plan is preferred in seven of eight cells (ranging from 54.11 to 72.54 percent) with six of eight cells showing backloaded contribution rates statistically different from a 50/50 split (all significant at the $\mathrm{p}=0.06$ level or better).

The remaining two cells are no different than a 50/50 split (54.11 and 44.09 percent). Importantly, both cells with statistical 50/50 splits are in the TAXES DOWN condition-where there is a strong economic incentive to prefer the front-loaded plan-consistent with H1. Additionally, when we compare all TAXES UP cells to all TAXES DOWN cells in Panel B, the preference for ROTHRATIO is significantly lower in the TAXES DOWN cells ( $\mathrm{p}<0.001)$, though still marginally above 50 percent ( 53.79 percent, $\mathrm{t}_{133}=1.321$, $\mathrm{p}_{\text {(one-tailed) }}=0.095$, untabulated). We interpret these findings as strong support for a general preference for a back-loaded (i.e., improving) pattern of taxation that is moderated by tax rate changes in accordance with $\mathrm{H3}$.

As predicted in H4, and consistent with the results of Experiment 2, we find a significant

\footnotetext{
${ }^{30}$ Our participants estimated their marginal tax rates by indicating how many dollars the liability on their most recent income tax return would have increased with an additional \$100 of taxable income. They were then presented with a detailed calculation of their marginal tax rate based on their response and asked to confirm or update their response.

${ }^{31}$ Note that we did not provide any subjects a tutorial on the relation of tax rate changes and relative plan returns. Therefore, we cannot test H2. However, unlike in experiment one, participants used tax rate changes in their plan choice even without such a tutorial.
} 
$(p=0.043)$ interaction between temporal distance and settlement position for our original model shown in Table 7. Further examination of the means plots (Figure 1) and simple effects (Table 9, Panel A) shows that when tax effects are temporally distant, there is no difference in the preference for back-loaded plans between the TAX DUE and REFUND settlement positions $\left(\mathrm{t}_{127}=0.982, \mathrm{p}_{\text {(two-tailed })}=0.328\right)$. On the other hand, when current tax effects are temporally immediate, there is a significantly higher preference for front-loaded plans in the TAX DUE settlement position compared to $R E F U N D\left(\mathrm{t}_{124}=1.439\right.$, $\left.\mathrm{p}_{\text {(two-tailed) }}=0.042\right)$. Additionally, a planned contrast consistent with the development of $\mathrm{H} 4$ is significant $\left(\mathrm{t}_{251}=1.735\right.$, $\left.\mathrm{p}_{\text {(one-tailed) }}=0.042\right)$ in Table 9, Panel B. Taken together, we interpret this evidence as additional support for H4—when participants face an immediate tax due, preference for front-loaded plans increases.

\section{Participant Savings Levels and Investment Selections}

As in our previous experiments, we performed additional untabulated analyses examining individual savings levels for Experiment 3. In a full ANOVA featuring temporal distance (DISTANT Vs. IMMEDIATE), tax position (TAXDUE vs. REFUND), and tax change (TAXESUP vs. TAXESDOWN), only the interaction of temporal distance and tax rate change is significant $\left(\mathrm{F}_{2}=3.459, \mathrm{p}=0.033\right)$. In contrast to the other tax change conditions, when tax rates are increasing, participants contribute more in the IMMEDIATE condition than the DISTANT condition. A two-sample t-test further shows that participants allocating 50 percent or more of their savings to a back-loaded plan saved less, on average, than participants allocating less than 50 percent to the front-loaded plan $\left(\$ 6,731.16\right.$ vs. $\left.\$ 7,397.85, \mathrm{t}_{371}=2.435, \mathrm{p}=0.015\right){ }^{32}$

As described above, Experiment 3 offered two hypothetical mutual funds that were common to each front- and back-loaded retirement plan. Across all conditions and back-loaded vs. front-loaded allocation choices, participants preferred the relatively aggressive Mutual Fund B by 52.4 percent to 47.2 percent over the relatively conservative Mutual Fund A, which differs from a 50/50 split ( $\mathrm{t}_{445}=1.968$, ptwo-tailed $\left.=0.050\right)$. Examining investment choice within subjects and within plan type, allocations to A and B did not differ by plan type. Investment in Mutual

\footnotetext{
32 This finding disappears in a regression of savings levels that includes all independent variables and a number of control variables. The regression produces two significant coefficients and three marginally significant coefficients. Household income, tax position (due/refund) importance, and a factor measuring procrastination and abdication of responsibility are all negatively associated with savings levels ( $\mathrm{p}=0.027, \mathrm{p}=0.028$, and $\mathrm{p}=0.108$, respectively). Savings levels are marginally positively associated with education level and risk preferences (both p-values=0.077). Predicting savings levels continues to be an elusive goal as in experiments one and two, as the model R2 is just 0.043
} 
Fund B averaged 62.19 percent in back-loaded plans and 64.08 percent in traditional plans, and the difference is statistically insignificant $\left(\mathrm{t}_{284}=1.302\right.$, $\left.\mathrm{p}_{\text {two-tailed }}=0.194\right)$.

Importantly, we do find that ROTHRATIO is significantly, negatively correlated with participants' total allocation to Mutual Fund B (Pearson correlation coefficient $=-0.130$, $\mathrm{p}=0.012$ ). That is, the higher participants' relative savings in a back-loaded plan, the lower their investment in the more aggressive asset. An independent samples t-test confirms this. We split participants based on those allocating 50 percent or more of their savings to a back-loaded plan. We find that those with a preference for a back-loaded plan have a mean allocation of 48.24 percent to Mutual Fund B, while those with a preference for a front-loaded plan have a mean allocation of 61.16 percent to Mutual Fund B $\left(\mathrm{t}_{372}=3.617, \mathrm{p}<0.001\right){ }^{33}$

\section{Replication of Experiment 3 and Additional Data Collection}

To assess the robustness of our findings in experiment three, we re-ran the experiment on a larger sample of MTurk participants and added an additional education manipulation (similar to the education modules featured in experiments one and two) that was not included in our original design. Our final sample consisted of 1,118 MTurk workers with demographic traits comparable to those displayed in Table 1. Overall, our partially tabulated analyses of Experiment 4 yielded results qualitatively and quantitatively similar to Experiment 3, with the exception that the preference for front-loaded plans in the temporally immediate, tax due condition identified in Experiment 3 did not replicate. ${ }^{34}$ Specifically, $\mathrm{H} 1$ is fully supported by Experiment 4 in Table 10, Figure 2; without education, decreasing future tax rates produce a mean ROTHRATIO of 60.82 percent, constant tax rates yield a mean ROTHRATIO of 70.99 percent, while increasing future tax rates resulted in a RоTнRATIO of 74.71 percent $\left(\mathrm{F}_{2}=39.165, \mathrm{p}<0.001\right)$.

The addition of an education manipulation allowed us to investigate the effects of education (H2) in a setting where participants received incentive compensation based on their

\footnotetext{
${ }^{33}$ The finding holds in a regression with all independent variables and a number of control variables, (std. $\beta=-0.109$, $\mathrm{t}=-1.974$, $\mathrm{p}_{\mathrm{two} \text {-tailed }}=0.049$ ). Using the same regression, we find that age, a factor score measuring confusion about taxes, a preference for prepayment, and risk preference are all positively associated with allocations to Mutual Fund B.

${ }^{34}$ Similar to experiment three, participants who allocated 50 percent or more of their retirement savings to the backloaded plan saved less than those participants who allocated a majority of their savings to the front-loaded plan $(\mathrm{t}=2.441, \mathrm{p}=0.015)$. Unlike in experiment three, this finding retains significance in a full multivariate regression model. The results of experiment three generally replicate in experiment four with respect to investment selections (i.e., allocations between Mutual Fund A and Mutual Fund B as described in experiment three).
} 
savings and investment choices. The interaction between the presence of education and tax rate changes is significant, supporting H2 (Table 10). Education magnifies the effects of tax rate changes on plan preference $\left(\mathrm{F}_{2}=4.754, \mathrm{p}=0.009\right)$ with decreasing taxes resulting in a mean ROTHRATIO of 45.03 percent compared to 73.12 percent in the presence of increasing tax rates.

Likewise, this additional experiment provides further evidence of a strong ceteris paribus preference for back-loaded plans compared to front-loaded plans. Of the 24 conditions tested, only two cells have a mean RоTнRATIO below 50 percent (38.00 percent and 38.33 percent) while another two cells are statistically indistinguishable from 50 percent (51.30 percent and 53.50 percent). Notably, all four of these cells have decreasing tax rates in the presence of education. The remaining 20 cells all have a mean ROTHRATIO statistically greater than 50 percent, ranging from 59.39 percent to 79.67 percent.

\section{Discussion and Conclusions}

Effectively stimulating retirement saving requires an understanding of how individuals make decisions about saving, including how they respond to common tax incentives. Research consistently suggests that individuals systematically violate economic axioms, incorporating non-economic factors into their investment decisions. An individual's relative economic returns from front-loaded and back-loaded retirement plans depend on the relationship between the tax rates faced by the individual when contributing to a plan and when receiving distributions. Neither individuals' expectations regarding current and future tax rates, nor their non-economic attitudes and preferences are observable in archival data, limiting the inferences that can be made based on that data.

We examine individual choices between front- and back-loaded plans using a series of online experiments. Evidence regarding individuals' reliance on expected tax rate changes when making such choices is mixed. Tax rate changes significantly impact plan choice when participants are educated regarding their economic effects and when participants are not educated but are randomly assigned to tax rate changes and paid based on the economic outcomes of their decisions. However, tax rate changes had no impact on plan choices when participants were neither educated on the economic impact of tax rate changes in advance nor experimentally prompted with information about the change. The results of these experiments suggest that individuals may not systematically rely on their beliefs regarding their relative tax rates when 
making plan choices but that at least part of that failure is due to a lack of awareness and/or understanding.

Although education increased participants' use of expected tax rate changes in their plan choices, participants continued to display an economically "irrational” preference for backloaded plans. This preference was found to be systematically related to participants' more general non-economic attitudes and preferences and the relation of these attitudes and preferences to the features of the plans being evaluated. In addition, our analyses suggest that individual saving levels are largely idiosyncratic and difficult to predict. However, we do find that investment risk preference is negatively associated with a preference for back-loaded plans and may be influenced by tax-related contextual variables as well.

Our findings should be of interest to policymakers interested in using the tax system to encourage saving. Consistent with prior research, our results suggest that individuals, on average, do not respond rationally to the relative economic incentives associated with alternatively structured plans. Further, although errors can be reduced with increased awareness, our evidence illustrates that individuals systematically incorporate non-economic factors into their retirement plan choices, often leading to a preference for back-loaded plans even when such a choice is economically adverse. While archival data show that retirement savers utilize frontloaded plans to a much greater extent than back-loaded Roth plans (70.6 percent vs. 23.1 percent of defined contribution retirement accounts) (Copeland 2015), the fact that we find a strong preference for back-loaded plans across several experiments and conditions suggests that the greater use of front-loaded plans is an artifact of artificial barriers to participation in back-loaded plans. Finally, one relatively consistent finding is that a sense of urgency regarding saving for retirement is positively associated with savings rates. While this is not surprising in itself, the current crisis in retirement preparedness suggests that current marketing and education campaigns are not sufficiently stoking investors' sense of urgency. Further research into the factors that increase a sense of urgency for retirement saving could be fruitful for future campaigns aimed at increasing savings rates.

Although we employ multiple experimental methods to enhance construct and external validity and employ a broad-based participant pool, our results and conclusions are subject to many of the caveats of most experimental research. For example, in spite of the similarities between our sample and the national population, MTurk participants who self-selected into the 
study may differ systematically from the general population. It is also possible that the education provided to participants about the relationship of tax rate changes and after-tax returns created a demand effect. However, participants' systematic preference for a plan that was economically dominated by another suggests that any demand effect was minimal. 


\section{References}

Allais, P. M. 1953. “Le Comportement De L’Homme Rationnel Devant Le Risque: Critique Des Postulates et Axiomes De L’Ecole Americaine.” Econometrica 21(4): 503-546.

Anderson, T. 2013. “The Surprising Origins of Your 401(k).” Investing Answers. Available at: http://www.nasdaq.com/article/the-surprising-origins-of-your-401k-cm258685

Banks, J., R. Blundell, and S. Tanner. 1998. “Is There a Retirement-Savings Puzzle?” American Economic Review 88(4):769-788.

Benartzi, S., and R. H. Thaler. 1999. "Risk Aversion or Myopia? Choices in Repeated Gambles and Retirement Investments.” Management Science 45(3): 364-381.

—. 2001. "Naïve Diversification Strategies in Defined Contribution Saving Plans.” American Economic Review 91(1): 79-98.

—. 2007. "Heuristics and Biases in Retirement Savings Behavior.” Journal of Economic Perspectives 21(3): 81-104.

Benzion, U., A. Rapoport, and J. Yagil. 1989. "Discount Rates Inferred from Decisions: An Experimental Study.” Management Science 35(3): 270-284.

Bonner, S. E., R. Hastie, G.B. Sprinkle, and S.M. Young. 2000. “A Review of the Effects of Financial Incentives on Performance in Laboratory Tasks: Implications for Management Accounting.” Journal of Management Accounting Research 12(1): 19-64.

Brandon, Duane M., James H. Long, Tina M. Loraas, Jennifer Mueller-Phillips, and Brian Vansant. 2014. “Online Instrument Delivery and Participant Recruitment Services: Emerging Opportunities for Behavioral Accounting Research.” Behavioral Research in Accounting 26(1): 1-23.

Brasel, K., M. M. Doxey, J. H. Grenier, and A. Reffett. 2016. "Risk Disclosure Preceding Negative Outcomes: The Effects of Reporting Critical Audit Matters on Judgments of Auditor Liability.” The Accounting Review 91(5): 1345-1362.

Brink, W. and L. Lee. 2015. “The Effect of Tax Preparation Software on Tax Compliance: A Research Note.” Behavioral Research in Accounting 27(1): 121-135.

Bryant, V. L. and P. J. Sailer. 2006. "Accumulation and Distribution of Individual Retirement Arrangements, 2001-2002.” SOI Bulletin: 233-254.

Buchheit, S., D. Dalton, T. Pollard, and S. Stinson. 2017. "How Smart Are Online Workers? A Student versus MTurk Participant Comparison.” Working paper. 
Buhrmester, M., T. Kwang, and S. Gosling. 2011. “Amazon’s Mechanical Turk: A New Source of Inexpensive Yet High-Quality Data?” Perspectives on Psychological Science 6(1): 35 .

Burman, L., E. W. Gale, and D. Weiner. 2001. “The Taxation of Retirement Savings: Choosing Between Front-Loaded and Back-Loaded Options.” National Tax Journal 54(3): 689702.

Calvert, L., J. Campbell, and P. Sodini. 2009. “Measuring the Financial Sophistication of Households.” American Economic Review 99(2): 393-398.

Clements, J. 2006. “Trimming Your Taxes: Why Roth 401(k)s Often Beat Conventional 401(k) Plans.” The Wall Street Journal. September 6: D1.

Copeland, C. 2007. “401(k)-type Plans and Individual Retirement Accounts (IRAs).” Employee Benefits Research Institute 28(10): 2-14.

- 2014. "Individual Retirement Account Balances, Contributions, and Rollovers, 2012: with Longitudinal Results 2010-2012: The EBRI Database.” Issue Brief 399. Washington, DC: Employee Benefits Research Institute.

—. 2015. "Individual retirement account balances, contributions, and rollovers, 2013: with longitudinal results 2010-2013: The EBRI Database.” Issue Brief 414. Washington, DC: Employee Benefits Research Institute.

Copeland, P. and A. Cuccia. 2002. "Multiple Determinants of Framing Referents in Tax Reporting and Compliance.” Organizational Behavior and Human Decision Processes 88(1): 499-526.

Einhorn, H. J. and R. M. Hogarth. 1985. “Ambiguity and Uncertainty in Probabilistic Inference.” Psychological Review 92(4): 433-461.

Farrell, A. M., J. H. Grenier, and J. Leiby. 2017. "Scoundrels or Stars? Theory and Evidence on the Quality of Workers in Online Labor Markets.” The Accounting Review 92(1): 93-114.

Hardisty, D., E. Johnson, and E. Weber. 2010. “A Dirty Word or s Dirty World? Attribute Framing, Political Affiliation, and Query Theory.” Psychological Science 21(1): 86-92.

Hardman, D. 2009. Judgment and Decision Making: Psychological Perspectives. West Sussex, U.K.: BPS Blackwell.

Hewitt Associates. 2006. “Hewitt Report Highlights Employee Use of Roth 401(k) Plans.” Press Release. Lincolnshire, IL. Available at: http://www.businesswire.com/news/home/20060627005103/en/Hewitt-ReportHighlights-Employee-Roth-401-Plans 
Hitlin, P. 2016. "Research in the Crowdsourcing Age: A Case Study.” Washington, DC: Pew Research Center.

Jackson, S. B. and R. C. Hatfield. 2005. "A Note on the Relation between Frames, Perceptions, and Taxpayer Behavior.” Contemporary Accounting Research 22(1): 145-164.

Kahneman, D. and A. Tversky. 1979. "Prospect Theory; an Analysis of Decision under Risk.” Econometrica 47(2): 363-391.

Loewenstein, G. 1987. “Anticipation and the Valuation of Delayed Consumption.” Economics Journal 97: 666-684

—. 1988. "Frames of Mind in Intertemporal Choice.” Management Science 34(2): 200-214.

Loewenstein, G. and D. Prelec. 1992. "Anomalies in Intertemporal Choice: Evidence and an Interpretation.” The Quarterly Journal of Economics 107(2): 573-597.

Loewenstein, G. and N. Sicherman. 1991. "Do Workers Prefer Increasing Wage Profiles?" Journal of Labor Economics 9(1): 67-84.

MacCrimmon, K. 1968. "Descriptive and Normative Implications of the Decision-Theory Postulates.” In Risk and Uncertainty, edited by K. Borch and J. Mossin, 3-32. New York: St. Martin's Press.

Moon, M. 2009. “How Do Americans Feel About Taxes Today?” Special Report No. 166. Washington, DC: Tax Foundation.

Muller, S. and M. Weber. 2010. "Financial Literacy and Mutual Fund Investments: Who Buys Actively Managed Funds?” Schmalenbach Business Review 62: 126-153.

Paolacci, G., J. Chandler, and P. G. Ipeirotis. 2010. "Running Experiments on Amazon Mechanical Turk.” Judgment and Decision Making 5(5): 411-419.

Prelec, D. and G. Loewenstein. 1998. "The Red and the Black: Mental Accounting of Savings and Debt.” Marketing Science 17(1): 4-28.

President's Advisory Panel on Federal Tax Reform. 2005. Simple, Fair and Pro-Growth: Proposals to Fix America's Tax System. Washington, DC.

Rennekamp, K. 2012. “Processing Fluency and Investors' Reactions to Disclosure Readability.” Journal of Accounting Research 50(5): 1319-1354.

Shelley, M. 1993. “Outcome Signs, Question Frames and Discount Rates.” Management Science 39(7): 806-815. 
Smith, H., M. Finke, and S. Huston. 2011. "The Impact of Financial Sophistication on Adjustable Rate Mortgage Ownership.” Journal of Financial Counseling and Planning 22(2): 3-15.

Slovic, P. and A. Tversky. 1974. “Who Accepts Savage's Axiom?” Behavioral Science 19(November): 368-73.

Stinson, S., M. Doxey, and T. Rupert. 2017. “The Effects of Income Tax Timing and Performance Feedback on Retirement Investment Decisions.” Working paper.

Thaler, R. 1981. “Some Empirical Evidence on Dynamic Inconsistency.” Economic Letters 8: 201-207.

—. 1994. "Psychology and Savings Policy.” American Economic Review 84(2): 186-192.

Tversky, A. and D. Kahneman. 1981. "The Framing of Decisions and the Psychology of Risk.” Science 211: 453-458.

—. 1991. "Loss Aversion in Riskless Choice: A Reference-Dependent Model.” Quarterly Journal of Economics 106(4): 1039-1061.

White, R., P. Harrison, and A. Harrell. 1993. “The Impact of Income Tax Withholding on Taxpayer Compliance: Further Empirical Evidence.” The Journal of the American Taxation Association 15(2): 63-78. 
Table 1. Sample Description

\begin{tabular}{|c|c|c|c|c|}
\hline & \multicolumn{3}{|c|}{ Study Sample } & \multirow[b]{2}{*}{$\begin{array}{l}\text { U.S. } \\
\text { Census }\end{array}$} \\
\hline & $\begin{array}{c}\text { Experiment } \\
\text { One }(\mathrm{N}=283)\end{array}$ & $\begin{array}{c}\text { Experiment } \\
\text { Two }(\mathrm{N}=293)\end{array}$ & $\begin{array}{c}\text { Experiment } \\
\text { Three }(\mathrm{N}=328)\end{array}$ & \\
\hline Age & 36 & 35 & 36 & 38 \\
\hline Female & $43 \%$ & $55 \%$ & $50 \%$ & $51 \%$ \\
\hline Family Income & $\$ 66,940$ & $\$ 64,192$ & $\$ 50,497$ & $\$ 53,900$ \\
\hline Married & $47 \%$ & $44 \%$ & $47 \%$ & $50 \%$ \\
\hline \multicolumn{5}{|l|}{ Education } \\
\hline High School & $25 \%$ & 26 & $19 \%$ & \multirow{2}{*}{$57 \%$} \\
\hline Some College & 18 & 20 & 21 & \\
\hline Bachelor's Degree & 41 & 42 & 42 & \multirow{2}{*}{30} \\
\hline Graduate School & 16 & 12 & 18 & \\
\hline Currently Save for Retirement & 69 & 73 & 82 & $\mathrm{n} / \mathrm{a}$ \\
\hline Expect tax rate in retirement to increase & 46 & 57 & 39 & $\mathrm{n} / \mathrm{a}$ \\
\hline $\begin{array}{l}\text { Confidence in direction of rate change } \\
(0=\text { none at all; } 100=\text { certain })\end{array}$ & 52 & 60 & 57 & $\mathrm{n} / \mathrm{a}$ \\
\hline Received Refund & 81 & 80 & 80 & 78 \\
\hline
\end{tabular}


Table 2. Experiment 1: Impact of Expected Tax Rate Changes on Retirement Plan Choice ${ }^{a}$

\begin{tabular}{|c|c|c|c|c|c|c|}
\hline \multicolumn{7}{|c|}{ Panel A: Repeated Measures ANCOVA Results } \\
\hline & \multicolumn{2}{|c|}{ Full Sample } & \multicolumn{2}{|c|}{ No Education } & \multicolumn{2}{|c|}{ Education } \\
\hline & $\mathrm{df}$ & Prob $<F$ & $\mathrm{df}$ & Prob $<$ F & $\mathrm{df}$ & Prob $<$ F \\
\hline \multicolumn{7}{|l|}{ Between Subjects Variables } \\
\hline Expected Rate Change $^{\mathrm{b}}$ & 1 & 0.005 & 1 & 0.710 & 1 & $<0.001$ \\
\hline Education $^{\mathrm{c}}$ & 1 & 0.166 & & & & \\
\hline Rate Change $\times$ Education & 1 & 0.020 & & & & \\
\hline Financial Sophistication $^{\mathrm{d}}$ & 1 & 0.004 & 1 & 0.023 & 1 & 0.084 \\
\hline Error & 278 & & 142 & & 135 & \\
\hline \multicolumn{7}{|l|}{ Within Subjects Factors } \\
\hline Temporal Distance ${ }^{\mathrm{a}}$ & 1 & 0.408 & 1 & 0.055 & 1 & 0.687 \\
\hline Distance $\times$ Expected Rate Change & 1 & 0.102 & 1 & 0.044 & 1 & 0.594 \\
\hline Distance $\times$ Education & 1 & 0.127 & & & & \\
\hline Distance $\times$ Rate Change $\times$ Educ & 1 & 0.434 & & & & \\
\hline Distance $\times$ Financial Sophistication & 1 & 0.247 & 1 & 0.229 & 1 & 0.633 \\
\hline Error & 278 & & 142 & & 135 & \\
\hline
\end{tabular}

Panel B: Least Squares Means

Expected Tax Rate Change

\begin{tabular}{lcc}
\cline { 2 - 3 } Education & $\begin{array}{c}\text { Increase in Retirement } \\
\text { 401(k) / IRA }\end{array}$ & $\begin{array}{c}\text { Decrease in Retirement } \\
\text { 401(k) / IRA }\end{array}$ \\
\hline None Provided & $-0.71 /-1.09$ & $-0.65 /-0.74$ \\
Provided & $-1.13 /-1.16$ & $0.02 / 0.05$ \\
\hline
\end{tabular}

\footnotetext{
${ }^{a}$ Participants chose whether they would prefer to participate in a front- or back-loaded retirement plan (1[6]=definitely back[front]-loaded). All responses were reduced by 3.5 so that positive (negative) numbers represent a preference for back(front)-loaded plans. The choice is made in two contexts: deciding about year-ahead withholding decisions, similar to participation in a 401(k) plan, and when completing a tax return, similar to an IRA contribution decision.

${ }^{\mathrm{b}}$ Participants predicted that their tax rate in retirement would be much lower (-3) or higher (3) than their current rate.

${ }^{\mathrm{C}}$ The impact of tax rate changes on the relative returns from front- and back-loaded plans was explained to half of study participants.

${ }^{d}$ Financial sophistication was captured by factor analyzing participants' general and business education as well as a self-assessment of their relative knowledge of personal finance and investing.
} 
Table 3. Experiment 1: Means and Correlation of Elicited Psychological Variables

Panel A: Means

\begin{tabular}{lrrrcc}
\hline Variable & Mean & Minimum & Maximum & $\mathrm{t}$ & $\operatorname{Pr}>|\mathrm{t}|$ \\
\hline Uncertainty Perceptions & -4.880 & -19.000 & 16.000 & 11.84 & $<\mathbf{0 . 0 0 1}$ \\
Prefer Prepayment & 1.403 & -3.000 & 3.000 & 13.01 & $<\mathbf{0 . 0 0 1}$ \\
Temporal Framing & 1.767 & -6.000 & 6.000 & 10.01 & $<\mathbf{0 . 0 0 1}$ \\
Dread / Discounting & 0.826 & -2.000 & 2.000 & 13.73 & $<\mathbf{0 . 0 0 1}$
\end{tabular}

Panel B: Pearson Correlations (p-values)

\begin{tabular}{lrrrrr}
\hline Variable & $\begin{array}{r}\text { Uncertainty } \\
\text { Perceptions }\end{array}$ & $\begin{array}{c}\text { Prefer } \\
\text { Prepayment }\end{array}$ & $\begin{array}{c}\text { Temporal } \\
\text { Framing }\end{array}$ & Dread & $\begin{array}{c}\text { Financial } \\
\text { Sophistication }\end{array}$ \\
\hline Uncertainty Perceptions & 1.000 & & & & \\
Prefer Prepayment & -0.065 & 1.000 & & & \\
& $(0.274)$ & & & & \\
Temporal Framing & -0.175 & 0.124 & 1.000 & & \\
& $(\mathbf{0 . 0 0 3})$ & $\mathbf{( 0 . 0 3 7 )}$ & & & \\
Dread & 0.023 & 0.020 & 0.095 & 1.000 & \\
& $(0.702)$ & $(0.734)$ & $(0.109)$ & & \\
Financial Sophistication & & & & & \\
& 0.050 & -0.039 & -0.057 & 0.011 & 1.000 \\
\hline
\end{tabular}


Table 4. Experiment 1: Moderating Effects of Non-Economic Factors on Retirement Plan Choice $^{a}$

Panel A: Regression Results

\begin{tabular}{|c|c|c|c|c|c|c|}
\hline & \multicolumn{2}{|c|}{ Full Sample } & \multicolumn{2}{|c|}{$\begin{array}{l}\text { Prepayment } \\
\text { Preferred }\end{array}$} & \multicolumn{2}{|c|}{$\begin{array}{l}\text { Prepayment Not } \\
\text { Preferred }\end{array}$} \\
\hline & $\mathrm{df}$ & $\begin{array}{l}\text { Prob } \\
<\mathrm{F}\end{array}$ & df & $\begin{array}{l}\text { Prob } \\
<\mathrm{F}\end{array}$ & $\mathrm{df}$ & $\begin{array}{l}\text { Prob } \\
<\mathrm{F}\end{array}$ \\
\hline \multicolumn{7}{|l|}{ Between Subjects Variables } \\
\hline Expected Rate Change (RC) & 1 & 0.120 & 1 & 0.166 & 1 & 0.500 \\
\hline Education (E) & 1 & 0.874 & 1 & 0.633 & 1 & 0.452 \\
\hline $\mathrm{RC} \times \mathrm{E}$ & 1 & 0.690 & 1 & $<0.001$ & 1 & 0.027 \\
\hline Financial Sophistication (FS) & 1 & 0.048 & 1 & 0.010 & 1 & 0.313 \\
\hline Preference for Prepayment $(\mathrm{PP})^{\mathrm{b}}$ & 1 & 0.900 & & & & \\
\hline $\mathrm{RC} \times \mathrm{PP}$ & 1 & 0.686 & & & & \\
\hline $\mathrm{E} \times \mathrm{PP}$ & 1 & 0.616 & & & & \\
\hline $\mathrm{RC} \times \mathrm{E} \times \mathrm{PP}$ & 1 & $<0.001$ & & & & \\
\hline Dread $(D)^{c}$ & 1 & 0.982 & 1 & 0.805 & 1 & 0.453 \\
\hline $\mathrm{RC} \times \mathrm{D}$ & 1 & 0.953 & 1 & 0.744 & 1 & 0.060 \\
\hline$E \times D$ & 1 & 0.661 & 1 & 0.282 & 1 & 0.857 \\
\hline $\mathrm{RC} \times \mathrm{E} \times \mathrm{D}$ & 1 & 0.070 & 1 & 0.178 & 1 & 0.264 \\
\hline Uncertainty (U) ${ }^{\mathrm{d}}$ & 1 & $<0.001$ & 1 & $<0.001$ & 1 & $<0.001$ \\
\hline $\mathrm{RC} \times \mathrm{U}$ & 1 & 0.164 & 1 & 0.169 & 1 & 0.254 \\
\hline $\mathrm{E} \times \mathrm{U}$ & 1 & 0.017 & 1 & 0.016 & 1 & 0.958 \\
\hline $\mathrm{RC} \times \mathrm{E} \times \mathrm{U}$ & 1 & 0.631 & 1 & 0.698 & 1 & 0.573 \\
\hline Payment/refund status (P/R) ${ }^{\mathrm{e}}$ & 1 & 0.048 & 1 & 0.010 & 1 & 0.182 \\
\hline $\mathrm{RC} \times \mathrm{P} / \mathrm{R}$ & 1 & 0.782 & 1 & 0.325 & 1 & 0.555 \\
\hline $\mathrm{E} \times \mathrm{P} / \mathrm{R}$ & 1 & 0.092 & 1 & 0.170 & 1 & 0.073 \\
\hline \multirow[t]{2}{*}{$\mathrm{RC} \times \mathrm{E} \times \mathrm{P} / \mathrm{R}$} & 1 & 0.840 & 1 & 0.569 & 1 & 0.016 \\
\hline & 262 & & 197 & & 61 & \\
\hline
\end{tabular}

Panel B: Least Square Means - Prepayment Not Preferred

\begin{tabular}{lccc}
\hline & \multicolumn{2}{c}{ Expected Tax Rate Change } & \\
\cline { 2 - 3 } Education & Increase in Retirement & Decrease in Retirement & \multirow{2}{*}{ Net change } \\
& 401(k)/ IRA & 401(k)/ IRA & \\
\hline None Provided & $-0.35 /-0.86$ & $-0.15 /-0.31$ & +0.75 \\
Provided & $-0.37 /-0.58$ & $-0.06 / 0.07$ & +0.82 \\
\hline
\end{tabular}


Panel C: Least Square Means - Prepayment Preferred

\begin{tabular}{lccc}
\hline & \multicolumn{2}{c}{ Expected Tax Rate Change } & \multirow{2}{*}{ Net Change } \\
\cline { 2 - 3 } Education & Increase in Retirement & Decrease in Retirement & \\
\hline None Provided & $401(\mathrm{k}) /$ IRA & $401(\mathrm{k}) /$ IRA & -2.51 \\
Provided & $0.19 /-0.45$ & $-0.57 /-0.49$ & +3.18
\end{tabular}

Panel D: Least Square Means - Prone to Dread

\begin{tabular}{lccc}
\hline & \multicolumn{2}{c}{ Expected Tax Rate Change } & \\
\cline { 2 - 3 } Education & Increase in Retirement & Decrease in Retirement & \multirow{2}{*}{ Net Change } \\
None Provided & $401(\mathrm{k}) /$ IRA & 401(k) / IRA & \\
Provided & $0.57 / 0.15$ & $-0.69 /-0.73$ & -0.70 \\
\hline & $-0.95 /-1.24$ & $0.48 / 0.82$ & +3.49
\end{tabular}

Panel E: Least Square Means - Not Prone to Dread

\begin{tabular}{|c|c|c|c|}
\hline \multirow[b]{2}{*}{ Education } & \multicolumn{2}{|c|}{ Expected Tax Rate Change } & \multirow[b]{2}{*}{ Net Change } \\
\hline & & & \\
\hline Nor & $-0.22 /-0.85$ & $-0.57 /-0.49$ & \\
\hline Provided & $-0.88 /-0.86$ & $0.03 /-0.13$ & \\
\hline \multicolumn{4}{|c|}{$\begin{array}{l}\text { a Participants chose whether they would prefer to participate in a front- or back-loaded retirement plan } \\
\text { (1[6]=definitely back[front]-loaded). All responses were reduced by } 3.5 \text { so that positive (negative) numbers } \\
\text { represent a preference for back(front)-loaded plans. The choice is made in two contexts: deciding about year-ahead } \\
\text { withholding decisions, similar to participation in a } 401(\mathrm{k} \text { ) plan, and when completing a tax return, similar to an IRA } \\
\text { contribution decision. } \\
\text { b Participants indicated whether they would prefer to finance living expenses during a month of unemployment by } \\
\text { saving money monthly prior to unemployment or to pay the same amount monthly after resuming work } 1 \text { (strongly } \\
\text { prefer after resuming work) to } 7 \text { (strongly prefer saving prior to unemployment). } \\
\text { c Participants were asked how much they would pay currently to avoid having to pay } \$ 5,000 \text { in one, } 10 \text { and } 20 \text { years } \\
\text { in the future. The amounts paid for a } 10 \text {-year and } 20 \text {-year delay were each subtracted from the amount paid for a } \\
\text { one-year delay and then divided by the amount paid for a one-year delay. A dread score was derived by summing } \\
\text { the two resulting ratios. } \\
\text { d The relative amount of uncertainty participants associated with a front-loaded plan was measured by asking } \\
\text { participants to describe the predictability of the tax costs and savings of each plan and subtracting the scores } \\
\text { provided for each plan. } \\
\text { e Participants provided the payment or refund due on their most recent tax return. }\end{array}$} \\
\hline
\end{tabular}


Table 5. Experiment 2: Means and Correlation of Elicited Psychological Variables

Panel A: Means

\begin{tabular}{lcrrrrr}
\hline Variable & $\mathrm{N}$ & Mean & Minimum & Maximum & $\mathrm{t}$ & $\mathrm{Pr}>|\mathrm{t}|$ \\
\hline Uncertainty Perceptions & 293 & -3.263 & -19.000 & 14.000 & --8.67 & $<\mathbf{0 . 0 0 1}$ \\
Prefer prepayment & 293 & 1.208 & -3.000 & 3.000 & 10.47 & $<\mathbf{0 . 0 0 1}$ \\
Temporal Framing & 293 & 1.584 & -6.000 & 6.000 & 9.61 & $<\mathbf{0 . 0 0 1}$ \\
Dread / Discounting & 293 & 0.858 & -19.000 & 14.000 & 8.67 & $<\mathbf{0 . 0 0 1}$ \\
& & & & & & \\
\hline
\end{tabular}

Panel B: Pearson Correlations (p-values)

\begin{tabular}{|c|c|c|c|c|c|}
\hline & $\begin{array}{l}\text { Uncertainty } \\
\text { Perceptions }\end{array}$ & $\begin{array}{c}\text { Prefer } \\
\text { Prepayment }\end{array}$ & $\begin{array}{c}\text { Temporal } \\
\text { Framing }\end{array}$ & Dread & $\begin{array}{c}\text { Financial. } \\
\text { Sophistication }\end{array}$ \\
\hline Uncertainty Perceptions & 1.000 & & & & \\
\hline Prefer Prepayment & $\begin{array}{l}-0.122 \\
(\mathbf{0 . 0 3 6})\end{array}$ & 1.000 & & & \\
\hline Temporal Framing & $\begin{array}{r}0.040 \\
(0.493)\end{array}$ & $\begin{array}{l}-0.002 \\
(0.972)\end{array}$ & 1.000 & & \\
\hline Dread & $\begin{array}{l}-0.059 \\
(0.318)\end{array}$ & $\begin{array}{r}0.053 \\
(0.372)\end{array}$ & $\begin{array}{r}0.044 \\
(0.452)\end{array}$ & 1.000 & \\
\hline Financial Sophistication & $\begin{array}{r}0.145 \\
(\mathbf{0 . 0 1 3})\end{array}$ & $\begin{array}{r}0.054 \\
(0.361)\end{array}$ & $\begin{array}{l}-0.012 \\
(0.838)\end{array}$ & $\begin{array}{l}-0.031 \\
(0.594)\end{array}$ & 1.000 \\
\hline
\end{tabular}


Table 6. Experiment 2: Effects of Psychological Factors on Plan Choice Holding Economic Effects Constant

\begin{tabular}{lrrrr}
\hline Source & DF & Type III SS & F & Pr > F \\
\hline Between-Subjects factors & & & & \\
Settlement position & 1 & 14.781 & 3.18 & $\mathbf{0 . 0 7 6}$ \\
Financial sophistication & 1 & 25.463 & 5.48 & $\mathbf{0 . 0 2 0}$ \\
Uncertainty perceptions & 1 & 140.170 & 30.18 & $<\mathbf{0 . 0 0 1}$ \\
Prepayment preferences & 1 & 14.992 & 14.99 & $\mathbf{0 . 0 7 4}$ \\
Temporal Framing & 1 & 48.228 & 10.38 & $\mathbf{0 . 0 0 1}$ \\
Dread & 1 & 2.617 & 0.56 & 0.454 \\
Error & 285 & $1,323.829$ & & \\
Within-subjects factors & & & & \\
Temporal distance & 1 & 4.648 & 5.82 & $\mathbf{0 . 0 1 6}$ \\
Distance $\times$ Settlement position & 1 & 3.372 & 4.22 & $\mathbf{0 . 0 4 1}$ \\
Distance $\times$ Financial sophistication & 1 & 0.321 & 0.40 & 0.526 \\
Distance $\times$ Uncertainty & 1 & 0.063 & 0.08 & 0.779 \\
Distance $\times$ Prepayment preferences & 1 & 1.417 & 1.77 & 0.184 \\
Distance $\times$ Temporal Framing & 1 & 0.334 & 0.42 & 0.518 \\
Distance $\times$ Dread & 1 & 0.616 & 0.77 & 0.380 \\
Error & 285 & 227.524 & & \\
\hline & & & & \\
\hline
\end{tabular}


Table 7. Experiment 3: ANOVA Results for ROTHRATIO

\begin{tabular}{lrrrrr}
\hline & Sum of & \multicolumn{2}{c}{ Mean } & & \\
Source of Variation & Squares & df & Square & \multicolumn{1}{c}{$\mathrm{F}$} & \multicolumn{1}{c}{$\mathrm{p}$} \\
\hline Model & 96.711 & 8 & 12.089 & 113.260 & $<\mathbf{0 . 0 0 1}$ \\
Temporal Distance (T) & $<0.001$ & 1 & $<0.001$ & 0.001 & 0.979 \\
Settlement position (S) & 0.023 & 1 & 0.023 & 0.212 & 0.645 \\
Tax Change & 1.353 & 1 & 1.353 & 12.676 & $<\mathbf{0 . 0 0 1}$ \\
$\mathrm{T} \times \mathrm{S}$ & 0.441 & 1 & 0.441 & 4.131 & $\mathbf{0 . 0 4 3}$ \\
$\mathrm{T} \times$ Tax Change & 0.081 & 1 & 0.081 & 0.758 & 0.385 \\
$\mathrm{~S} \times$ Tax Change & 0.138 & 1 & 0.138 & 1.289 & 0.257 \\
$\mathrm{~T} \times \mathrm{S} \times$ Tax Change & 0.017 & 1 & 0.017 & 0.164 & 0.686 \\
Error & 26.364 & 247 & 0.107 & & \\
\hline
\end{tabular}

Table 8. Experiment 3: Comparison of ROTHRATIO Across All Cells and By Individual Cell

Panel A: RothRATIO Comparison to 50\%

\begin{tabular}{|c|c|c|c|c|c|c|c|c|c|}
\hline & Cell & & Mean & $\mathrm{N}$ & S.D. & $\mathrm{t}$ & df & $\mathrm{p}_{\text {(two-tailed) }}$ & $\mathrm{P}_{\text {(one-tailed) }}$ \\
\hline \multicolumn{3}{|l|}{ All Conditions } & $60.90 \%$ & 255 & $33.51 \%$ & 5.193 & 254 & $<0.001$ & $<0.001$ \\
\hline \multirow[t]{4}{*}{ TAXES UP } & TAX & DISTANT & $71.62 \%$ & 29 & $29.40 \%$ & 3.960 & 28 & $<0.001$ & $<0.001$ \\
\hline & DuE & IMMEDIATE & $68.62 \%$ & 27 & $31.60 \%$ & 3.062 & 26 & 0.005 & 0.003 \\
\hline & REFUND & DISTANT & $62.16 \%$ & 33 & $37.94 \%$ & 1.841 & 32 & 0.075 & 0.038 \\
\hline & & IMMEDIATE & $72.54 \%$ & 33 & $29.86 \%$ & 4.336 & 32 & $<0.001$ & $<0.001$ \\
\hline TAXES & TAX & DISTANT & $57.57 \%$ & 35 & $28.22 \%$ & 1.587 & 34 & 0.122 & 0.061 \\
\hline \multirow[t]{3}{*}{ Down } & DuE & IMMEDIATE & $44.09 \%$ & 36 & $35.20 \%$ & -1.008 & 35 & 0.321 & 0.840 \\
\hline & REFUND & DISTANT & $54.11 \%$ & 32 & $35.33 \%$ & 0.659 & 31 & 0.515 & 0.258 \\
\hline & & IMMEDIATE & $60.66 \%$ & 30 & $32.03 \%$ & 1.823 & 29 & 0.079 & 0.040 \\
\hline
\end{tabular}

Panel B: RothRATIO for Increasing vs. Decreasing Taxes

\begin{tabular}{llllllll}
\hline TAXES UP & $68.65 \%$ & 122 & $32.38 \%$ & \multirow{2}{*}{3.622} & 253 & $<0.001$ & $<$ \\
TAXES DOWN & $53.79 \%$ & 133 & $33.05 \%$ & & \multirow{2}{*}{001} \\
\hline
\end{tabular}


Table 9. Experiment 3: Analyses of Simple Effects and Planned Contrast

Panel A: Simple Effects

\begin{tabular}{lrrrrrc}
\hline Temporal & \multicolumn{2}{c}{ ROTHRATIO } & & & & \\
Distance & TAX DUE & REFUND & \multicolumn{1}{c}{ diff } & \multicolumn{1}{c}{ t } & df & P(two-tailed) \\
\hline DISTANT & $63.94 \%$ & $58.20 \%$ & $5.74 \%$ & $0.982^{\mathrm{a}}$ & 122 & 0.328 \\
IMMEDIATE & $54.60 \%$ & $66.88 \%$ & $-12.28 \%$ & -2.057 & 124 & $\mathbf{0 . 0 4 2}$ \\
\hline
\end{tabular}

Panel B: Results of Planned Contrast

\begin{tabular}{|c|c|c|c|c|c|c|}
\hline \multirow{2}{*}{$\begin{array}{c}\text { Temporal } \\
\text { Distance }\end{array}$} & \multicolumn{2}{|c|}{$\begin{array}{c}\text { Contrast } \\
\text { Coefficients }\end{array}$} & \multirow{2}{*}{$\begin{array}{c}\text { Contrast } \\
\text { Value }\end{array}$} & \multirow[b]{2}{*}{$\mathrm{t}$} & \multirow[b]{2}{*}{$\mathrm{df}$} & \multirow[b]{2}{*}{$\mathrm{P}$ (one-tailed) } \\
\hline & TAX DuE & REFUND & & & & \\
\hline DISTANT & 1 & 1 & 0252 & 1735 & 251 & 0.042 \\
\hline IMMEDIATE & -3 & 1 & & & & \\
\hline
\end{tabular}

${ }^{a}$ Welch's t utilized due to heterogeneity of variance.

Table 10. Experiment 4: ANOVA Results for ROTHRATIO

\begin{tabular}{lrrrrr}
\hline \multicolumn{1}{c}{ Source of Variation } & Sum of & \multicolumn{5}{c}{ Mean } & & \\
\hline Squares & \multicolumn{1}{c}{ df } & Square & \multicolumn{1}{c}{$\mathrm{F}$} & \multicolumn{1}{c}{ p } \\
Education & 488.817 & 6 & 81.470 & 726.692 & $<\mathbf{0 . 0 0 1}$ \\
Tax Change & $<0.001$ & 1 & 1.371 & 12.230 & $<\mathbf{0 . 0 0 1}$ \\
Education $\times$ Tax Change & 0.023 & 2 & 4.391 & 39.165 & $<\mathbf{0 . 0 0 1}$ \\
Error & 1.353 & 2 & 0.533 & 4.754 & $\mathbf{0 . 0 0 9}$ \\
\hline
\end{tabular}


Figure 1. Experiment 3: Means Plot of RothRATIO by Temporal Distance and Settlement Position

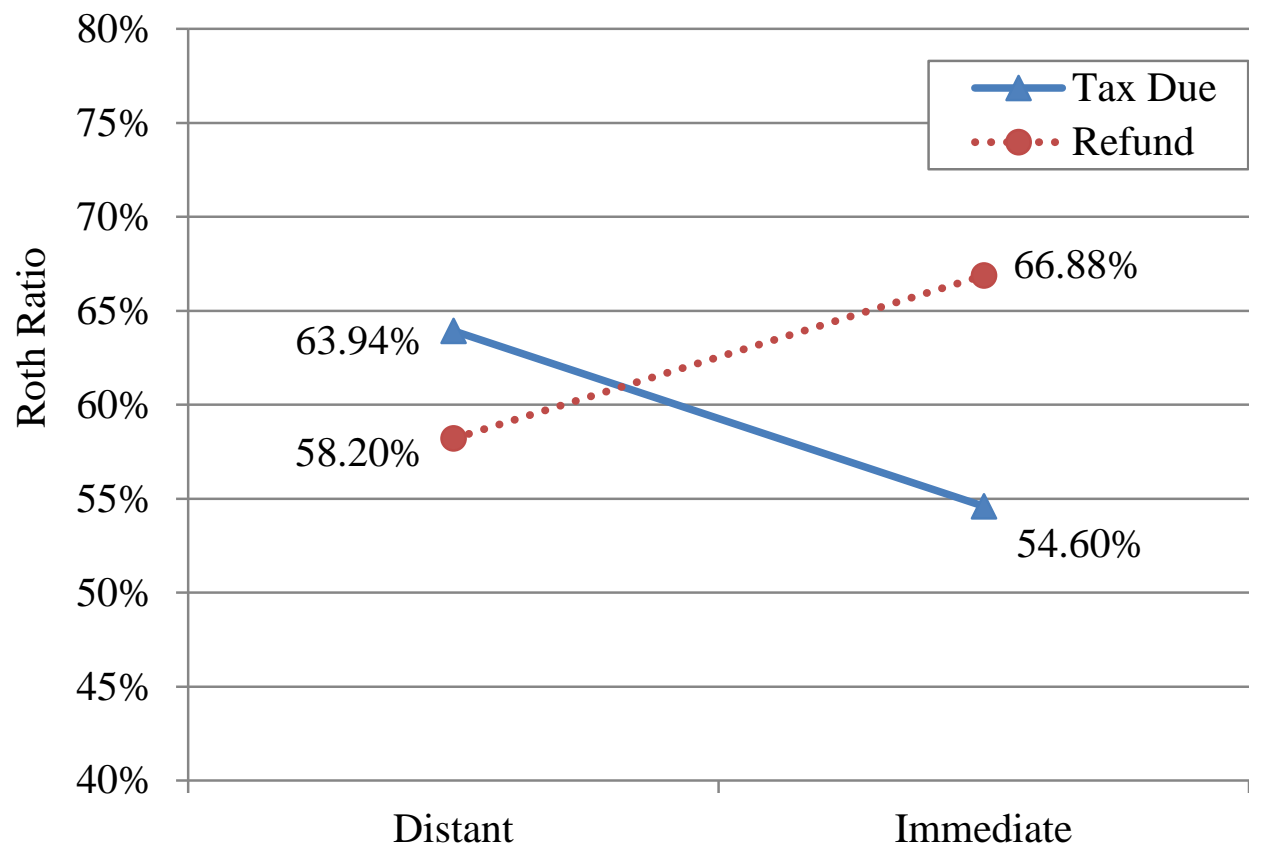

Figure 2. Experiment 4: Means Plot of RothRATIO by Tax Rate Change and Education

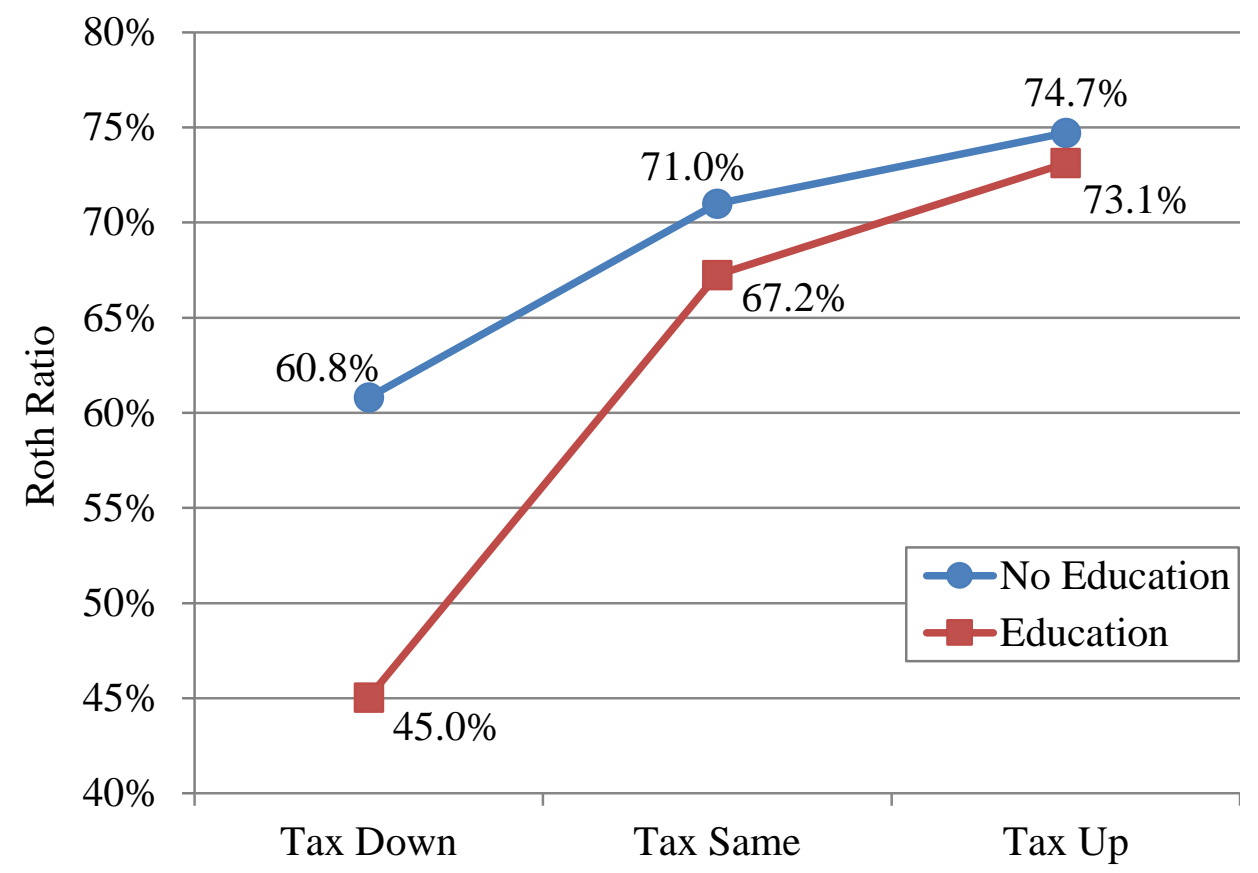




\section{Appendix}

The after-tax return of an investment can be described as follows:

$$
\left[\mathrm{r}\left(1-\mathrm{t}_{\mathrm{i}}\right)\right]^{\mathrm{n}}
$$

where $\quad r=$ rate of return on invested capital,

$\mathrm{t}_{\mathrm{i}}=$ the tax rate on investment income, and

$\mathrm{n}=$ the number of periods invested.

The ability to defer taxes on investment income until it is withdrawn results in the following:

$$
[r]^{\mathrm{n}}\left(1-\mathrm{t}_{\mathrm{w} / \mathrm{d}}\right)
$$

where $t_{w / d}$ represents the tax rate applicable to withdrawals and all else is as before. Further allowing the deduction of the initial investment, as is done in traditional front-loaded savings plans, leads to the following as long as the tax savings from the deduction can be invested at the same rate of return in the same, or a similar, tax-deferred investment:

$$
\frac{[\mathrm{r}]^{\mathrm{n}}\left(1-\mathrm{t}_{\mathrm{w} / \mathrm{d}}\right)}{\left(1-\mathrm{t}_{\text {ded }}\right) .}
$$

Assuming that the current tax rate on deducted savings is equal to the eventual rate on withdrawal, the rate of return on a traditional, front-loaded savings plans reduces to $\mathrm{r}^{\mathrm{n}}$. Thus, the rate of return available from front-loaded plans is equivalent to the tax-free rate available from back-loaded plans as long as (1) the taxpayer can reinvest the initial tax savings generated by the front-loaded plan at the same rate of return in the same or similar tax-deferred investment; and (2) the tax rate on current deductions is equal to that on eventual withdrawals. Assuming that the typical taxpayer can reinvest current tax savings from a front-loaded plan, the primary economic factor determining plan-type dominance is the direction of expected tax rate changes, which depends on the taxpayer's earnings pattern as well as temporal changes in the statutory tax rate. 


\section{Exhibit 1. Example Education Module}

Before we get to the decisions we'd like you to make, please review the following. You must understand this information in order to make the decisions you will be asked to make.

Lawmakers have considered various types of tax-favored retirement plans over time. Below are two such plans. The plans are similar to each other in many respects, though they differ from currently available plans. Both provide tax benefits to anyone making contributions toward their retirement. Further, both plans:

- Have no limit on the amount that can be contributed (i.e., you can contribute as much of your income as you like to either plan);

- Require that your contributions stay in the plan until retirement - early withdrawal will trigger a $10 \%$ penalty in addition to any tax that might be owed;

- Allow withdrawals at any time after retirement and in any amount without penalty;

- Have the same investment options, including most investments you might make outside of a retirement account (e.g., bank deposits, stocks, bonds, mutual funds, etc.).

The differences between the plans are outlined below. To keep them straight, we'll call the plans Smith and Jones. Please read them over and answer a few questions to confirm your understanding of them.

[The order of the plan descriptions and tax rate explanations was randomized between subjects.]

\begin{tabular}{|l|l|}
\hline $\begin{array}{l}\text { Smith } \\
\text { Retirement } \\
\text { Plan }\end{array}$ & $\begin{array}{l}\text { Contributions to the plan will not change your current taxes. Any amount } \\
\text { contributed to the plan will still be included in your taxable income and will be } \\
\text { taxed at your current tax rate. However, you will not owe any taxes on the } \\
\text { contribution or the earnings it generates when you withdraw it at retirement. }\end{array}$ \\
\hline $\begin{array}{l}\text { Jones } \\
\text { Retirement } \\
\text { Plan }\end{array}$ & $\begin{array}{l}\text { Contributions to the plan will reduce your current taxes. Any amount contributed } \\
\text { to the plan will be excluded from your taxable income and will reduce this year's } \\
\text { taxes by the contribution amount multiplied by your current tax rate (i.e., } \\
\text { contribution x current tax rate). However, you will owe taxes at your future tax } \\
\text { rate on the contribution and the earnings it generates when you withdraw it at } \\
\text { retirement. }\end{array}$ \\
\hline
\end{tabular}

As described above, both plans will provide tax savings for anyone choosing to participate. Which plan will provide the most money overall for retirement is determined in large part by how your current tax rate compares to what it might be when you retire and withdraw your contributions and savings.

The Smith Plan requires you to pay taxes now but allows you to avoid taxes later when you withdraw your savings at retirement. If you expect your tax rate to be higher in retirement than it is now, the Smith Plan may provide more money for retirement, after taxes, by allowing you to pay taxes when your rate is lower. 
Alternatively, the Jones Plan allows you to avoid taxes now but requires you to pay taxes later when you withdraw your savings at retirement. If you expect your tax rate to be lower in retirement than it is now, the Jones Plan may provide more money for retirement, after taxes, by allowing you to pay taxes when your rate is lower.

Finally, if you expect your tax rate to be the same in retirement as it is now, both the Smith and Jones plans should provide the same amount of money for retirement. In other words, choosing between the plans allows you to choose when you will pay taxes and when you will avoid them, but in either instance the tax rate you pay and the amount of after-tax dollars available to you for retirement will be the same.

Please answer the following questions to confirm your understanding of the plans.

[The order of the questions was randomized. The order of answer choices was also adjusted to match the randomly assigned order of plan descriptions presented above. Participants could not advance to the next screen until all three questions were answered correctly.]

Jane has decided that she wants to devote a certain portion of her salary (before any applicable taxes) to her retirement savings each year. Jane's current tax rate is $30 \%$, and she expects to pay a tax rate of 35\% after she retires. Assuming she's correct about her future tax rate, which plan will likely offer more money after taxes when Jane retires?
a. Smith Retirement Plan
b. Jones Retirement Plan
c. Both plans offer the same amount of money after taxes

Mary has decided that she wants to devote a certain portion of her salary (before any applicable taxes) to her retirement savings each year. Mary's current tax rate is $28 \%$, and she expects to pay a tax rate of $23 \%$ after she retires. Assuming she's correct about her future tax rate, which plan will likely offer more money after taxes when Mary retires?
a. Smith Retirement Plan
b. Jones Retirement Plan
c. Both plans offer the same amount of money after taxes

Courtney has decided that she wants to devote a certain portion of her salary (before any applicable taxes) to her retirement savings each year. Courtney's current tax rate is $25 \%$, and she expects to pay a tax rate of $25 \%$ after she retires. Assuming she's correct about her future tax rate, which plan will likely offer more money after taxes when Courtney retires?
a. Smith Retirement Plan
b. Jones Retirement Plan
c. Both plans offer the same amount of money after taxes 


\section{RECENT WORKING PAPERS FROM THE CENTER FOR RETIREMENT RESEARCH AT BOSTON COLLEGE}

Social Security and Total Replacement Rates in Disability and Retirement Mashfiqur R. Khan, Matthew S. Rutledge, and Geoffrey T. Sanzenbacher, May 2017

An Experimental Analysis of Modifications to the Survivor Benefit Information within the Social Security Statement Jeffrey Diebold and Susan Camilleri, May 2017

Actuarial Inputs and the Valuation of Public Pension Liabilities and Contribution Requirements: A Simulation Approach

Gang Chen and David S. T. Matkin, May 2017

Why Are U.S. Households Claiming Social Security Later?

Wenliang Hou, Alicia H. Munnell, Geoffrey T. Sanzenbacher, and Yinji Li, April 2017

Rising Inequality in Life Expectancy by Socioeconomic Status

Geoffrey T. Sanzenbacher, Anthony Webb, Candace M. Cosgrove, and Natalia S. Orlova, April 2017

The Effect of Job Mobility on Retirement Timing by Education

Geoffrey T. Sanzenbacher, Steven A. Sass, and Christopher M. Gillis, February 2017

Would Reducing the Price of Employing an Older Worker Improve Labor Market Outcomes by Socioeconomic Status? Evidence from Health Insurance Premium Restrictions

Matthew S. Rutledge and Caroline V. Crawford, December 2016

The Impact of Massachusetts Health Insurance Reform on Labor Mobility

Norma B. Coe, Wenliang Hou, Alicia H. Munnell, Patrick J. Purcell, and Matthew S. Rutledge, December 2016

Work, Retirement, and Social Networks at Older Ages

Eleonora Patacchini and Gary V. Engelhardt, November 2016

Calculating Expected Social Security Benefits by Race, Education, and Claiming Age

Geoffrey T. Sanzenbacher and Jorge D. Ramos-Mercado, November 2016

Do Late-Career Wages Boost Social Security More for Women than Men?

Matthew S. Rutledge and John E. Lindner, November 2016

All working papers are available on the Center for Retirement Research website (http://crr.bc.edu) and can be requested by e-mail (crr@bc.edu) or phone (617-552-1762). 